\title{
Paleoenvironmental framework of dinosaur tracksites and other ichnofossils in Early Cretaceous mixed siliciclastic-carbonate deposits in the Neuquén Basin, northern Patagonia (Argentina)
}

\author{
P.J. Pazos ${ }^{\text {a,b,* }}$, D.G. Lazo ${ }^{\text {a,b }}$, M.A. Tunik ${ }^{\text {b,c }}$, C.A. Marsicano ${ }^{\text {a,b }}$, D.E. Fernández ${ }^{\text {a,b }}$, M.B. Aguirre-Urreta ${ }^{\text {a,b }}$

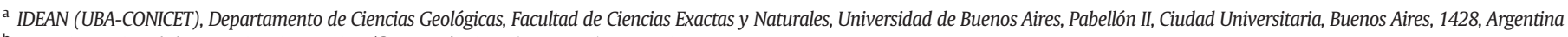 \\ b Consejo Nacional de Investigaciones Científicas y Técnicas (CONICET), Argentina \\ c Departamento de Geología, Universidad Nacional de Río Negro, Argentina
}

\section{A R T I C L E I N F O}

\section{Article history:}

Received 1 April 2011

Received in revised form 27 December 2011

Accepted 1 February 2012

Available online 15 February 2012

Handling Editor: J.G. Meert

\section{Keywords:}

Tidal cycles

Dinosaur tracks

Cretaceous

Carbonates

Neuquén Basin

Patagonia

Argentina

\begin{abstract}
A B S T R A C T
The study of the uppermost section of the Early Cretaceous Agrio Formation in northern Patagonia (Neuquén Basin) where dinosaur tracks assigned to cf. Therangospodus pandemicus are exposed (tracksites I and II) evidence mixed marginal marine siliciclastic-carbonate deposits. The succession was divided in two intervals. A lower one containing theropod tracks, recorded on top of subtidal oolithic limestones with tiny wave ripples suggesting shoreline fluctuations and subaerial exposure. Tidal influence is recognised by fining upward and prograding cycles starting with subtidal carbonates and ending with fine-grained siliciclastic deposits at the top, or rarely laminites. Dolomitization affects subtidal deposits generated in an alkaline media stressful for tracemakers. Intertidal facies include abundant heterolithic deposits, coquinas composed of gastropods encrusted by multilayered bryozoans and muddy levels with incipient mud cracking. Invertebrate ichnofossils recognized from tidally dominated deposits include Arenicolites, Kouphichnium, and Rhizocorallium. The upper interval is a transgressive-regressive cycle that starts with dark shales, deficiently oxygenated, and covered by prograding sandstones and finally sand flat deposits. This interval contains Gyrochorte, Hillichnus, and Ophiomorpha documented in wave-influenced sandstones. Dinosaur tracks as well as Hillichnus, attributed to tellinoid bivalves, and Kouphichnium assigned to xiphosurans, imply the activity of producers rarely recorded previously as body fossils in marginal marine deposits of southern South America. Previous paleogeographic schemes are questioned by our analysis, which shows evidence of extremely shallow and tide-controlled sedimentation, sometimes with subaerial exposure, with high cyclicity related to a marginal marine depositional setting and lack of significant erosion by the overlying unit, as traditionally was suggested.
\end{abstract}

(c) 2012 International Association for Gondwana Research. Published by Elsevier B.V. All rights reserved.

\section{Introduction}

During the Early Cretaceous, particularly during the Late HauterivianEarly Barremian, one of the most important transgressions from the Pacific took place in the Neuquén Basin (Aguirre-Urreta et al., 2008). It was interrupted only by a forced regression that intercalated continental deposits. This scenario was documented several times during the Jurassic and Cretaceous in the basin (Veiga et al., 2005; Veiga and Spalletti, 2007) conversely Atlantic ingresions during the Latest Cretaceous are related to the Andean uplift and document the disconnection with the Pacific (Aguirre-Urreta et al., 2011). The marine basin is interpreted as a carbonate ramp mainly dominated by storms events (Spalletti et al., 2001; Cichowolski et al., 2012). In this work we document a marginal marine depositional setting, tidally dominated and composed of mixed

\footnotetext{
* Corresponding author at: IDEAN (UBA-CONICET), Departamento de Ciencias Geológicas, Facultad de Ciencias Exactas y Naturales, Universidad de Buenos Aires, Pabellón II, Ciudad Universitaria, Buenos Aires, 1428, Argentina. Tel./fax: +5411 45763329.

E-mail address: pazos@gl.fcen.uba.ar (P.J. Pazos).
}

siliciclastic-carbonate deposits containing theropod tracks that evidence subaerial exposure of the Agrio Formation deposits in an area interpreted previously as permanent submerged in facies and paleogeographic maps (e.g. Legarreta, 2002).

Recently, numerous studies have documented dinosaur tracksites from various regions (e.g., Belvedere et al., 2011), including the Mesozoic marginal marine carbonates mainly from Jurassic deposits in the Alps (e.g. Nicosia et al., 2007), British Columbia in Canada (Zonneveld et al., 2001), the Bighorn Basin in USA (Kvale et al., 2001) and the Early Cretaceous of the peri-Adriatic Basin (Sacchi et al., 2009; Petti et al., 2010). Interestingly, in the Mediterranean basins dinosaur tracks have been used as an unequivocal evidence of exposure of carbonate platforms that questioned previous paleogeographic reconstructions between southern Europe and Africa during the Jurassic-Cretaceous (Zarcone et al., 2010). Other records from Triassic carbonate tidal flats are also very common in Europe (Dietrich, 2002, 2008). In Patagonia, non-avian dinosaur footprints are known since the '60s, when Casamiquela (1964) described several small tridactyl tracks from continental deposits of the Middle Jurassic of Santa Cruz Province (La Matilde 
Formation). Since then, many tracks and trackways attributed to dinosaurs have been mentioned from several localities in Patagonia, mainly in Cretaceous continental successions from the Neuquén Basin (e.g. Calvo, 1991; Calvo and Mazzetta, 2004; Calvo, 2007). In particular, the first record of footprints referred to non-avian theropods was only recorded from Late Cretaceous continental deposits of the Candeleros Formation in the basin (Leanza et al., 2004). Older records of theropod dinosaurs in the basin are restricted to fragmentary skeletal remains of a small theropod from the Barremian continental red beds of La Amarga Formation, partially equivalent to the Agrio Formation in nonmarine settings (Salgado and Bonaparte, 1991; Bonaparte, 1996; Leanza et al., 2004; Apesteguía, 2007; Coria, 2007).

The Neuquén Basin is one of the best known Mesozoic Andean basins in South America. Sedimentologically, it has been extensively studied because of its rich hydrocarbon content, and facies analysis has been the basis of the most accepted paleogeographic reconstructions of the basin infilling (e.g. Legarreta, 2002).

In the marine succession recorded by the Agrio Formation a diverse fauna of invertebrates has been documented (see Lazo et al., 2005 and references therein). However, the uppermost section of the unit, which is the interval studied herein, has an extremely scarce record of macro and microfossils. This situation has been used to speculate about the presence of an erosive incision related to a sea level drop which is recorded by the overlying fluvial and aeolian deposits of the Huitrín Formation (e.g. Leanza et al., 2001). Interestingly, the upper section of the Agrio Formation contains an abundant and diverse trace fossil record including ichnofossils (Pazos et al., 2008; Pazos, 2009; Fernández et al., 2010; Pazos and Fernández, 2010), and strong evidence of salinity fluctuations and mixture of marine and meteoric waters (Lazo et al., 2008; Tunik et al., 2009).

The aim of this contribution is to study and to provide an accurate sedimentological context to the stratigraphic interval bearing two theropod tracksites, analyse the paleobiological significance of the tracks, discuss the systematic conflicting ichnotaxonomy of theropod tracks, document the associated ichnofossils in a facies framework from the upper part of the Agrio Formation cropping out in Neuquén Province (northern Patagonia) and to propose a new depositional setting evidencing strong tidal influence that invite to revise paleogeographical models for an oil reservoir unit.

\section{Geological setting and methods}

The Neuquén Basin located in west-central Argentina is a retro-arc basin developed on a convergent continental margin (Legarreta and Uliana, 1999). It extends from $32^{\circ}$ to $40^{\circ} \mathrm{S}$ along the Andean foothills and south of $36^{\circ} \mathrm{S}$ forms a large NW-SE orientated marine embayment (Fig. 1a). This embayment was land-locked eastwards and southward but was connected to the Pacific Ocean through an active volcanic arc during most of its Mesozoic history. In particular, deposition of the Agrio Formation started during the early Valanginian as a result of a gradual relative sea level rise that largely onlapped the basin. This unit crops out extensively in the Neuquén Province as a series of meridian anticlines along the Agrio fold and thrust belt (Fig. 1, Ramos, 1978). Near Bajada del Agrio, close to the stratotype of the unit, it reaches approximately $1200 \mathrm{~m}$ in thickness being divided into three members: Pilmatué, Avilé, and Agua de la Mula (Weaver, 1931; Leanza et al., 2001). The Pilmatué and Agua de la Mula Members consist of shales, siltstones, sandstones and limestone beds of marine origin. The Avilé Member is a continental sandstone package (fluvial to aeolian) accumulated overlying the Pilmatué Member during a forced regression in the middle Hauterivian (Veiga et al., 2002, 2005). The Pilmatué and Agua de la Mula Members contain mainly shales and limestones (bioclastic dominantly) and have been interpreted to represent shoreface to offshore paleoenvironments on a storm-dominated, shallow-marine ramp (e.g. Spalletti et al., 2001). In the upper member three depositional sequences have been recognised. The lower ones are siliciclastic dominated and the upper one is interpreted in terms of carbonatic environments according to Archuby and Fürsich (2010). The upper contact of the unit is a sequence boundary, or a master sequence boundary according to Strömback et al. (2005). The overlying Huitrín Formation comprises sandstones, limestones, and evaporites that denote the final stages of connection of the basin to the Pacific Ocean during Barremian to Aptian times (Legarreta, 2002). The biostratigraphic framework is based on a detailed ammonoid zonation that has been recently strengthen by a precise age dating by U-Pb SHRIMP on zircons in the Agua de la Mula Member (Aguirre-Urreta et al., 2008). The age of the studied succession, based on the mentioned zonation, is latest Hauterivian possibly reaching the basal Barremian (Aguirre-Urreta et al., 2005).

The tracksites studied here (Fig. 1b) are Mina La Continental (tracksite I) and Cerro Rayoso (tracksite II). The first one is in the eastern flank of a strongly tectonically disturbed anticline (Pichi Mahuida) that involves the Agua de la Mula Member and the overlying Huitrín Formation, close to an abandoned barite mine. Tracksite II is situated in the eastern flank of a more homogeneous structure named Cerro Rayoso anticline, where the Agua de la Mula Member and the Huitrin and Rayoso Formations are well-exposed. Approximately the uppermost $30 \mathrm{~m}$ of the Agua de la Mula Member were surveyed after an unexpected discovery of theropod tracks in both localities during a field trip.

The tracksite I was logged bed by bed (Fig. 2a); lithofacies were defined and interpreted and traces and body fossils collected. Key beds were sampled for petrographic studies and classified following Dunham (1962) and Flügel (2004) for carbonate types, Folk et al. (1970) for siliciclastic types, and Mount (1984) for the mixed siliciclastic-carbonate samples. Sedimentary composition and dolomite cementation related to the dinosaur tracks bearing beds have been recently documented from tracksite I by Tunik et al. (2009). These studies were also improved using scanning electron microscope (SEM) analysis performed on gold-coated freshly broken surfaces using a Philips SEM 515 microscope with an accelerating voltage of $20 \mathrm{kV}$ and with an attached energy dispersive analyser (EDAX) at the Universidad Nacional del Comahue. In tracksite II petrographic sampling was limited to host rock and infilling of the tracks and only the short interval containing them was included in the lithofacies scheme.

Invertebrate trace fossils were ichnotaxonomically classified and resumed in a table (Table 1) and each mentioned ichnogenus was illustrated in alphabetic order. The dinosaur tracks were described in the field and a scaled map of the tracking surfaces was constructed using a grid and morphometric measurements grouped (Table 2) and compared. Invertebrate trace fossils were described and photographed in the field and sampled when possible. The collected materials are housed in the Area de Paleontología, Facultad de Ciencias Exactas y Naturales, Universidad de Buenos Aires, Pabellón 2, Ciudad Universitaria, Buenos Aires (CPBA).

\section{Sedimentary Facies}

\subsection{Oolithic grainstones-packstones}

\subsubsection{Description}

It is documented in both tracksites and contains the dinosaur tracks. In the field it exhibits a distinct dewatered iron-related orange colour and occurs in decimetric beds. In tracksite I they are separated by thin grey mudstones that preserve relatively large dinosaur tracks with abundant wave ripples with $\mathrm{N}-\mathrm{S}$ axis affecting differentially some trackways (Fig. 2b). The bed packing is very regular and in some cases, beds are thicker and show bipolar (flood-ebb) and onshore dominated paleocurrents. In tracksite II (Fig. 3a) the tracks are related to very small wave ripples with approximately $\mathrm{N}-\mathrm{S}$ axis were documented (Fig. 3b).

In thin sections these carbonates are classified as medium to coarsegrained dolo-grainstones (Fig. 4a) to packstones composed of abundant ooids, sometimes dissolved as in tracksite II (Fig. 4b), and scarce bioclasts showing an important dolomite replacement (Fig. 4a). In addition, bladed and blocky isopachous and granular void filling dolomite 
are quite common; scarce late blocky calcite was also identified (Fig. 4a). The dolomite in the samples can be classified as polimodal, planar-s dolomite with mimetic or non-mimetic textures after Sibley and Gregg (1987). Ooids are the main framework grains (Fig. 4a, b, c, d). They range between 0.1 and $0.5 \mathrm{~mm}$ and can be classified as Type 1 of Strasser (1986) as well-rounded micritic ooids with tiny laminated cortices. Ooid nuclei are commonly composed of quartz, feldspar or more rarely dolomite or sparite. The presence of truncated ooids at the top of the bed and an iron (?) stained crust is noticeable. In much less proportion fragments of echinoderms, oysters, other bivalves, and bryozoans were identified (Fig. 4a, b).

\subsubsection{Interpretation}

Grainstones and packstones dominated by well-sorted ooids suggest an autochthonous subaqueous origin in agitated shallow waters and onshore movement by flooding tidal currents from fully subtidal to subtidal-intertidal areas with minor transport, during lowering of the sea level, while the dinosaur tracks indicate subaerial exposure. This exposure was probably due to rapid emergence evidencing autocyclic high cyclicity and rapidly fluctuating water level due to wind as suggested in intertidal settings by Kvale et al. (2001). Stained crusts in some grainstone beds also suggest at least short subaerial exposure but truncated ooids indicate some grade of lithification or stabilization prior to erosion possibly in response to microbial mat stabilization. Petrographic studies indicate that both the host substratum and infill of tracks are similar, suggesting that the sediment filled the depressions of the tracks soon after their generation and both exhibit the same diagenetic processes. The dolomite crystal characteristics (Fig. 4c, d) and the mimetic replacement of entire rocks correlate with an absence of mud, high porosity, high permeability of the sediment and thus active fluid flow and faster crystal growth during early diagenetic stages (Gregg and Sibley, 1984; Dawans and Swart, 1988; Vahrenkamp and Swart, 1994; Warren, 2000).

\subsection{Laminites}

\subsubsection{Description}

It is represented by decimetric carbonate laminites (Fig. 2e) with corrugated surfaces, sometimes brecciated. The carbonate lamination is millimetre-scaled (Fig. 4). Their texture is characterized by alternating thin micrite layers, siliciclastic layers, and horizontally dispersed elongated fenestrae as empty or calcite filled pores. The fenestrae are mostly irregular, but some show flat roofs and irregular bottoms (Fig. 2e). The irregularity of the fenestrae indicates the soft nature of the sediment (Flügel, 2004).

\subsubsection{Interpretation}

This facies can be classified as fenestral bindstones.The precipitation of carbonate forming laminites was biologically induced and indicates inter to supratidal conditions (Flügel, 2004). Probably microbial mats were involved in the precipitation as it is usually the case with dolomite in supratidal sabkhas (Bontognali et al., 2010).

\subsection{Bioclastic deposits}

\subsubsection{Description}

This facies is very peculiar because it represents loosely-packed sandy limestones (coquinas) up to $25 \mathrm{~cm}$ thick, mainly composed of gastropods but also some bivalve shells and serpulids occur. Beds may be channeled conforming lenses, or laterally extended pavements. Most of the shells show a high degree of dissolution, abrasion, and encrustation and variable degrees of disarticulation and fragmentation. Gastropods, in particular, are highly encrusted by multilayered cheilostome bryozoans mixed with thin and tortuous serpulid tubes showing variable external corrosion (Taylor et al., 2009, Figs. 3 and 4). Gastropods can be referred to the Family Potamididae of the Superfamily Cerithioidea (sensu Keen, 1958, p. 306) while the bryozoans, recently studied by Taylor et al. (2009), are assigned to the Family Electridae of the Suborder Malacostegina.

Besides potamidids, there is a second less abundant gastropod species that has a low-spired shell, heavily encrusted by bryzoans and corroded, with a large body whorl with a prominent cord of tubercles on its shoulder. At present the collected material is not enough for precise identification, but it is comparable to Lissochilus sp. nov. (Superfamily Neritoidea, Family Neritidae) described from the Ortiz Formation (Tithonian-Berriasian) by Manceñido and Damborenea (1984, pl. 2, figs. 2-5).

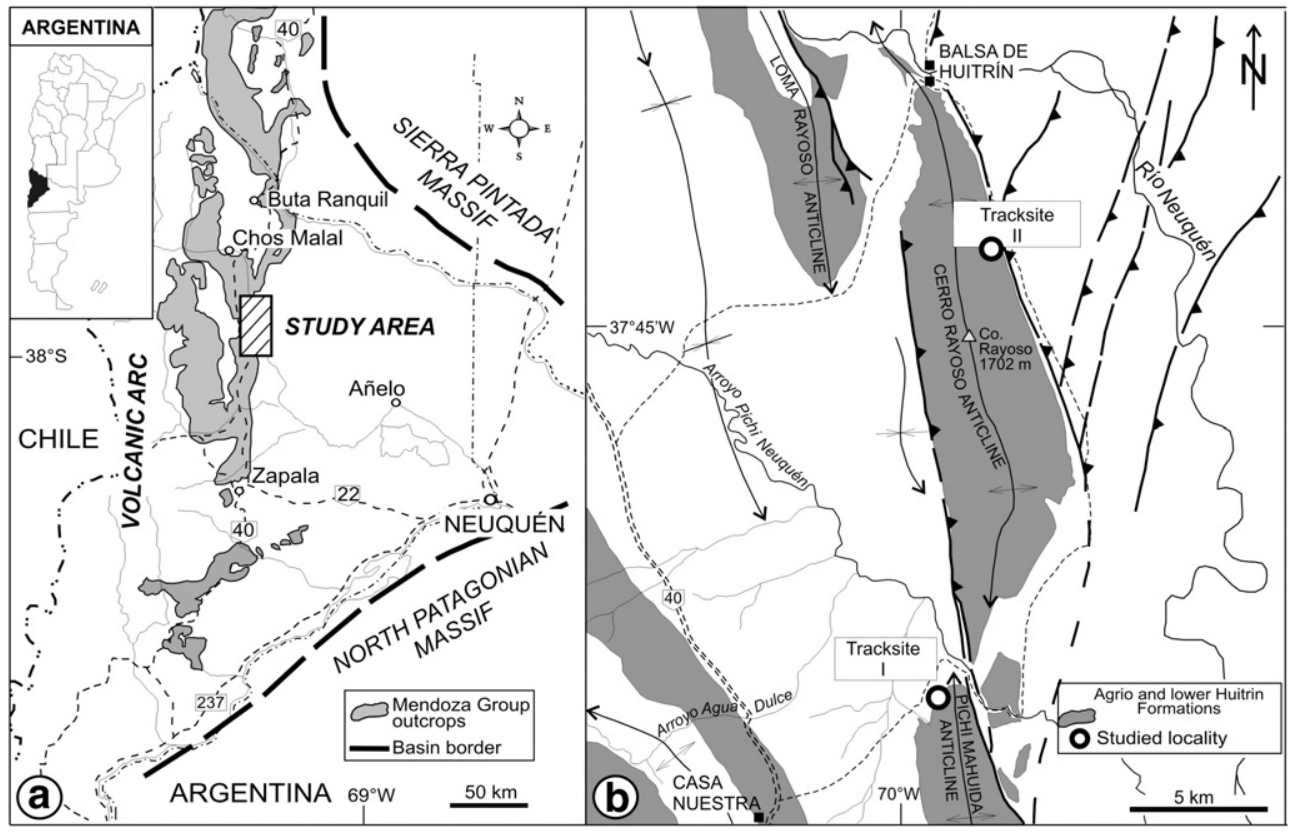

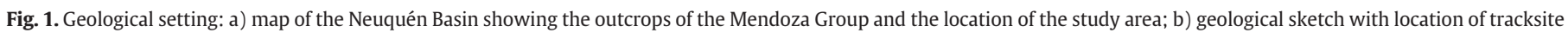
I Mina La Continental and tracksite II Cerro Rayoso. 


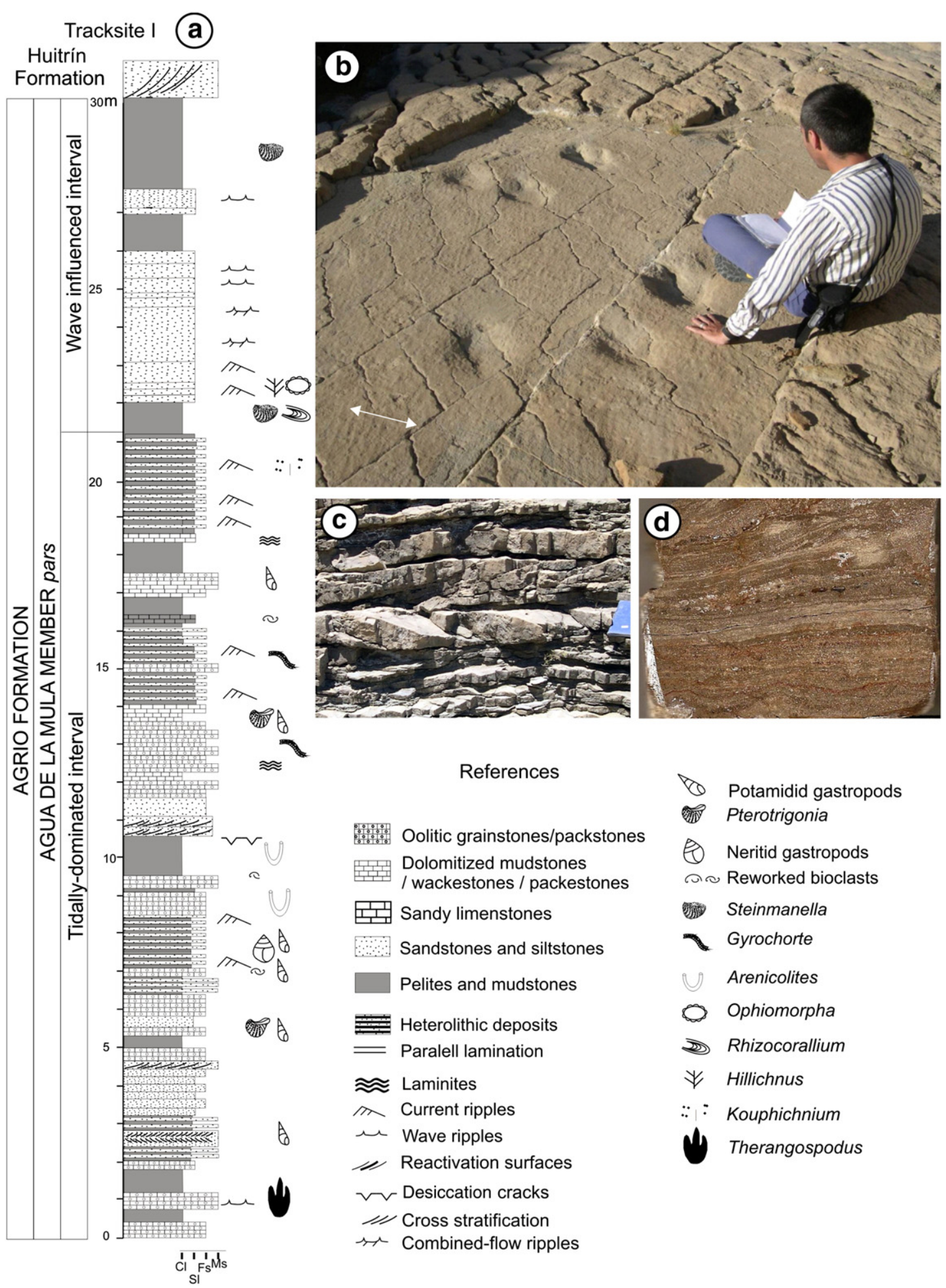

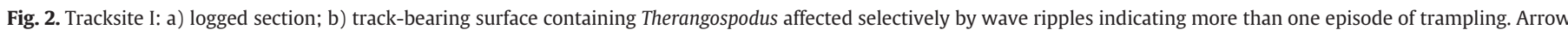
shows ripple axis; c) tidal opposite paleocurrents; d) polished slab of laminites.

Bivalves are represented by two species of the Superfamily Trigonioidea: Pterotrigonia coihuicoensis (Weaver) and Steinmanella vacaensis (Weaver). Scattered fragments of undetermined pterioid bivalves were also recorded. All the examined trigonioid specimens showed a moderate to high degree of external encrustation by the mentioned multilayered cheilostome colonies and isolated cyclostomes and serpulids. However, the high degree of external corrosion complicates a more precise identification.

\subsubsection{Interpretation}

These deposits are interpreted to represent small tidal creeks that reintroduce bioclasts moved to the coast during flood periods and remobilised them into channels during the ebb part of the tidal cycle. These beds present condensed macrobenthic assemblages suggesting that environmental change was more rapid relative to net rates of sediment aggradation and thus taxa from successive habitats formed a single shell bed (see Kidwell and Bosence, 1991). The 
Table 1

Integrated information about invertebrate ichnology, including potencial tracemakers, facies distribution and a short description.

\begin{tabular}{|c|c|c|c|c|}
\hline Ichnogenus & Figure & Description & $\begin{array}{l}\text { Possible producers and } \\
\text { ethological interpretation }\end{array}$ & $\begin{array}{l}\text { Facies in which } \\
\text { they are found }\end{array}$ \\
\hline Arenicolites & $6 a$ & $\begin{array}{l}\text { Paired opening tubes with external circular outline. The diameter varies from } 0.5 \text { up to } \\
1 \mathrm{~cm} \text {. The infilling is of a slightly paler colour than the host rock indicating variation in } \\
\text { grain size or cementation. }\end{array}$ & $\begin{array}{l}\text { Dwelling/feeding burrows of } \\
\text { filter-feeding organisms. }\end{array}$ & Dark shales \\
\hline Gyrochorte & $6 b$ & $\begin{array}{l}\text { Trails composed of positive bilobated epirelief crests from } 0.3 \text { to } 0.5 \mathrm{~cm} \text { in width. Oblique } \\
\text { spreiten is not visible but constrictions were detected. Preserved mostly as negative } \\
\text { hiporelief, but some epichnial casts have also been observed. }\end{array}$ & $\begin{array}{l}\text { Locomotion trace. The producers are } \\
\text { endobenthic, possibly gastropods, } \\
\text { crustaceans or worms. }\end{array}$ & Grey sandstones \\
\hline Hillichnus & $6 c$ & $\begin{array}{l}\text { Three-dimensional structures resembling a plant frond with a central stem. On bedding } \\
\text { planes, the stems show alternating branches curved or straight, depicted at different } \\
\text { angles from a central tube. Associated elements include aligned tubes forming strings and } \\
\text { vertical shafts. Size is up to } 15 \mathrm{~cm} \text { in length and } 8 \mathrm{~cm} \text { width. }\end{array}$ & $\begin{array}{l}\text { Compound trace (involving locomotion, } \\
\text { feeding, respiration and defaecation) } \\
\text { produced by tellinoid bivalves. }\end{array}$ & Grey sandstones \\
\hline Kouphichnium & $6 \mathrm{~d}$ & $\begin{array}{l}\text { Trackways preserved as concave epirelief showing rows of symmetrically arranged imprints, } \\
\text { with sinuous or straight course, recording surface impressions and shallow undertracks. } \\
\text { Regular leg and "pusher" leg marks are common. Medial drag marks are conspicuous and } \\
\text { continuous but not always present. External trackway width is } 25 \mathrm{~mm} \text { in average. }\end{array}$ & Trackways produced by xiphosurids. & $\begin{array}{l}\text { Grey shales and } \\
\text { sandstones }\end{array}$ \\
\hline Ophiomorpha & $6 e$ & $\begin{array}{l}\text { Horizontal and vertical burrows lined with agglutinated pelleted sediment. Branching or } \\
\text { networks are not always clear. Diameter of the burrow is } 1.5 \mathrm{~cm} \text {. The lining is smooth on } \\
\text { the interior and irregular to mammillated or nodose on the exterior surface. Pellets are } \\
\text { ovoid to irregular in shape; in some cases are muddy and in others inorganic particles } \\
\text { (mica?) are used as lining. }\end{array}$ & $\begin{array}{l}\text { Feeding and dwelling traces produced } \\
\text { mainly by callianasid decapods. }\end{array}$ & $\begin{array}{l}\text { Grey sandstones } \\
\text { Coarsening upward } \\
\text { sandstones }\end{array}$ \\
\hline Rhizocorallium & $6 f$ & $\begin{array}{l}\text { Subhorizontal to U-shaped tubes with short ending vertical projections. External tube } \\
\text { infilled with sandy sediment. Protrusive spreiten with alternation of dark and light laminae } \\
\text { (mud and fine-grained sand alternations). Size increases towards the curved part (mar- } \\
\text { ginal tunnel), resembling a vase; maximum length is up to } 8 \mathrm{~cm} \text { and distance between } \\
\text { tubes never exceeds } 5 \mathrm{~cm} \text {. }\end{array}$ & $\begin{array}{l}\text { Dwelling structures made by } \\
\text { suspensivorous organisms. }\end{array}$ & Dark shales \\
\hline
\end{tabular}

overall taphonomic imprint suggests a parautochthonous origin with a low degree of lateral transport.

The ecological requirements of recent potamidids have been studied by Bandel and Kowalke (1999). These gastropods represent common intertidal snails with an amphibious existence on muddy habitats confined to tropical and subtropical regions. They settle in mangrove swamps and on salt marshes and mud flats where they feed on detritus and graze microalgae. They are also prominent in equivalent saltmarsh and mudflat habitats in warm-temperate areas. They usually move during low tides preferring soft muddy portions of the coastal swamp beneath the trees and occasionally attaching to the mangrove roots and trunks during high tide (Bandel and Kowalke, 1999; Kowalke, 2002; Barnes, 2003). Most species are common and occur in large, sometimes enormous, populations. Some species occur in densities as high as 13,800 snails $/ \mathrm{m}^{2}$ (Houbrick, 1984, 1986). They have been restricted to brackish waters habitats, especially mangroves, at least since the Coniacian. They include genera with direct or indirect development, indicating different adaptations to isolated coastal swamps and open water environments such as bays and estuaries (Kowalke, 2002). All the studied potamidids are fully covered by multilamellar cheilostome masses hiding their ornamentation suggesting changes in salinity (see Taylor et al., 2009).

\subsection{Grey sandstones}

\subsubsection{Description}

It is composed of fine to medium-grained, grey to greenish sandstones containing abundant micas that at outcrop scale evidence offshore progradation. The thickness is $2.3 \mathrm{~m}$ and the interval contains combined ebb-dominated and unidirectional and purely wave ripples. Parallel lamination is very frequent and some intervals look massive but this could be an artefact of extremely well-sorted and dense packing conditions. This facies was described and illustrated in detail by Pazos and Fernández (2010) because it contains the complex threedimensional trace fossil Hillichnus agrioensis (Pazos and Fernández, 2010) attributed to tellinoid bivalves, as well as the ichnogenera Ophiomorpha and Gyrochorte. Petrographic analyses of the sandstones characterize them as subfeldarenite to feldarenite. Quartz is the main component (Fig. 4f), the common type being monocrystalline, though the polycrystalline type is also easily recognized. The identified feldspars are plagioclase and alkaline feldspar. The accessory elements are micas, mainly biotite and muscovite, and zircons. The cements in order of abundance are: secondary quartz, carbonatic cement (calcite and barite from X-ray analysis, see Tunik et al., 2009) and illite as rim cement. The detritic components are diagenetically aligned and flexured. The grain to grain contacts are sharp or punctual and in less proportion sutured (Fig. 4f).

\subsubsection{Interpretation}

This lithofacies documents a change in the infilling from permanent subaqueous deposits settled from suspension (dark shales, see below) to sandy permanent subaqueous deposits that strongly prograded towards the north. This facies is interpreted to represent a prograding wedge and a turnover from tidal to a wave dominated depositional setting. Strong progradation indicates high input from the continent. Dominance of an offshore paleocurrent pattern and combined-flow ripples document a combination of oscillatory and unidirectional flows and trace fossils document normal marine environments rather than a salinity fluctuating scenario.

\subsection{Coarsening upward siltstones and sandstones}

\subsubsection{Description}

This type of deposits is only recorded in tracksite II (Fig. 3a) and consists of a coarsening upward succession of a couple of metres scale that starts with siltstone containing wave ripples, parallel lamination and passes upward to unidirectional cross stratification with mud drapes. The lower contact is transitional from mudstones and the upper one is sharp with carbonates containing tracksite II surface. Horizontal turning vertical galleries of Ophiomorpha are very abundant in the entire interval but particularly in the lower levels of the coarsening upward section.

\subsubsection{Interpretation}

These deposits evidence a shallowing upward trend, strongly progradational that starts with oscillatory dominated flows replaced by unidirectional flows, offshore directed showing reactivation surfaces related to tidal cyclicity. Interestingly the coarsening upward pattern is not the typical one observed in a progradation of a tidal flat and due to the short interval analysed in this paper just a preliminarily interpretation is suggested. Stacked coarsening upward packages were 
Table 2

Measures of the trackways analyzed in Tracksites I and II. All measures are expressed in cm; n.d., not datum.

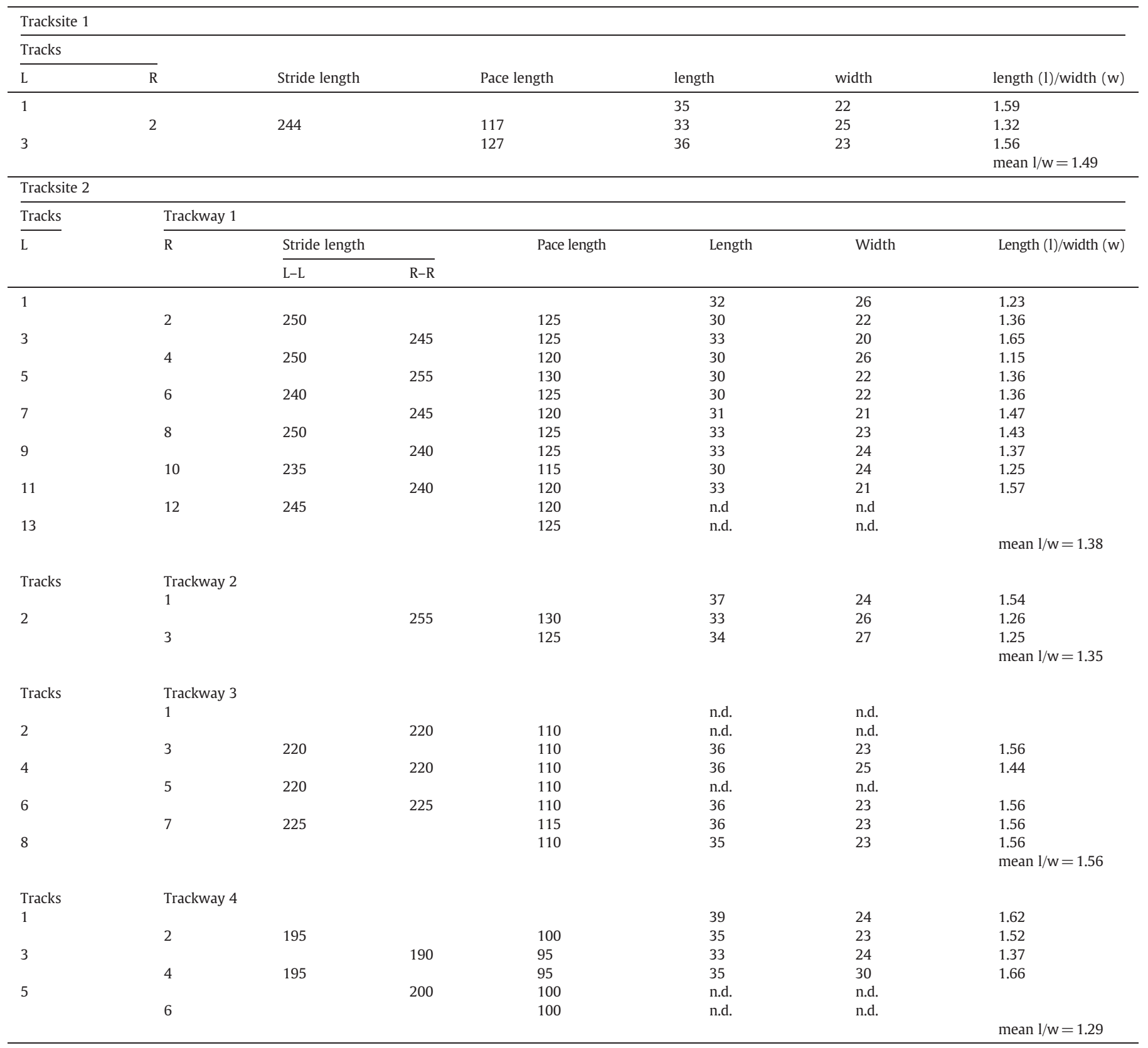

observed in the field and they probably reflect progradation of tidally dominated delta lobes. The sharp upper contact where siliciclastic deposits are replaced by carbonates documents a flooding surface, siliciclastic starvation and carbonate precipitation in shallow and agitated waters. Ophiomorpha is a common ichnofossil in wave and tidal dominated deposits in the Agrio Formation (Pazos, 2009).

\subsection{Sandstone-dominated heterolithic deposits}

\subsubsection{Description}

It is characterized by repetition of metric current rippled sandstone beds intercalated with grey shales. Sandstone beds are decimetric in thickness (Fig. 2c) with poorly preserved ripples containing mud drapes (Tunik et al., 2009; Pazos and Fernández, 2010). They are characterized by opposite paleocurrent directions with a dominant flood direction (SE) over the ebb ones (NW). Internally this facies is fining upwards and almost barren of trace fossils being only represented by scarce endichnial vertical tubes. Some intervals of grey shales up to $5 \mathrm{~cm}$ in thickness are intensively bioturbated with primary fabric almost completely destroyed.

\subsubsection{Interpretation}

It represents a mixed intertidal flat and records repetitive tidal cycles without any clear internal arrangement. No double mud drapes were identified and a flood-dominated paleocurrent pattern is dominant over the ebb records. It is possible that the thicker fine-grained deposits represent a short-lived muddy record of the upper intertidal deposits, evidencing cycles of high frequency.

\subsection{Green shales and sandstones}

\subsubsection{Description}

These deposits are several metres thick in tracksite I, have a regional extension to the south of the basin, and may be considered the top of 


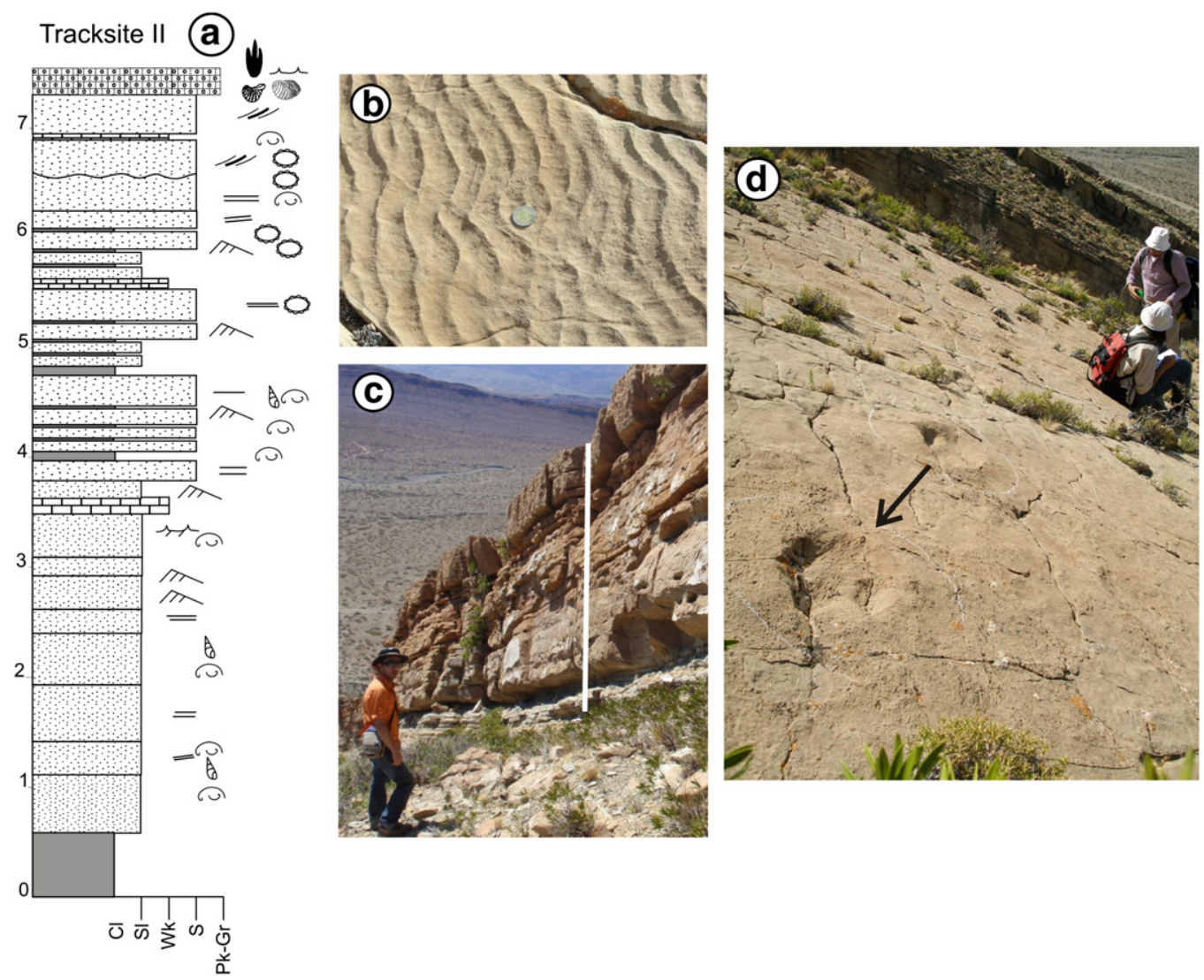

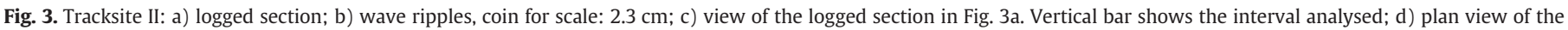
track-bearing surface, with a track (arrow) in a highly tilted flank of Cerro Rayoso. Key symbols as in Fig. 2.

the Agrio Formation. They are also present in tracksite II but $25 \mathrm{~m}$ above the logged section. This interval is composed of silty shales with an intense green colour and intercalations of fine-grained sandstones. The sandstones are parallel laminated with parting lineation or rippled. Wave ripples show amplitudes of $2-3 \mathrm{~cm}$ and in plan view some are top-flat. Trace fossils are absent and body fossils very scarce, only an isolated valve of Steinmanella vacaensis has been recorded.

\subsubsection{Interpretation}

This lithofacies documents deposition in a very shallow depositional setting, with strong unidirectional currents under upper flow regime (parting lineation) and intervals under oscillatory flows (wave ripples) and final subaerial exposure documented by top-flat ripples. A mixed sandy-mud flat is envisaged for this facies.

\subsection{Gray shales and sandstones}

\subsubsection{Description}

They are dominated by grey siltstones and claystones interstratified with starved unidirectional ripples and, less commonly, wave ripples occasionally top-flat. Very thin channelled sandstones containing fragmented bioclasts were rarely observed. In general, the stacking pattern is fining upwards with a predominance of fine-grained sediments and a veneer of sandstone close to the top. Unidirectional flooddominated ripples are more abundant than wave ripples and ebborientated ripples. Mud cracks, when present, are mainly at the top of the facies. It is classified as allochemic sandstones and sandy allochemic limestones after Mount (1984). It includes a mixture of fragmented bioclasts, oolites, quartz, and feldspar. Ichnologically it contains invertebrate trackways (Kouphichnium) preserved on top of unidirectional ripples and covered by thin mud layers.

\subsubsection{Interpretation}

The fining upward arrangement records the change from lower middle intertidal (sandy dominated) to upper intertidal (muddy dominated) environments. The almost complete absence of ebb-orientated ripples indicates reduced fluvial discharge. Top-flat ripples and mud cracks suggest occasional exposure of unconsolidated substrates. Fragmented bioclasts were moved onshore during tidal onset. Mud drapes and shales indicate a typical tidal modulated depositional setting and the increased cohesive behaviour of the substrate can explain the scarcity of trace fossils. Kouphichnium trackways document the activity of xiphosuran in these intertidal settings as was recently suggested by Fernández and Pazos (2010).

\subsection{Dark shales}

\subsubsection{Description}

It consists of recurrent intervals of dark to light gray shales with thin fine-grained sandstone intercalations. The basal contact is transitional from heterolithic deposits and the upper one is sharp. The shales are internally parallel laminated, or massive. Organic matter and plant debris content is high. It occurs in packages that present both a fining upward and slightly coarsening upward trend. Thickness varies from $1 \mathrm{~m}$ (tracksite II) to $2 \mathrm{~m}$ (tracksite I). Body fossils are absent in tracksite II, but some isolated valves of Steinmanella vacaensis and gastropods encrusted by bryozoans have been documented in tracksite I.

\subsubsection{Interpretation}

They record deposition from suspension, but also deficient oxygenation is consistent with the abundant organic matter and plant debris preserved in the darkest coloured shales (tracksite I). It suggests at least a low energy depositional setting protected from tidal/storm currents. Incipient 

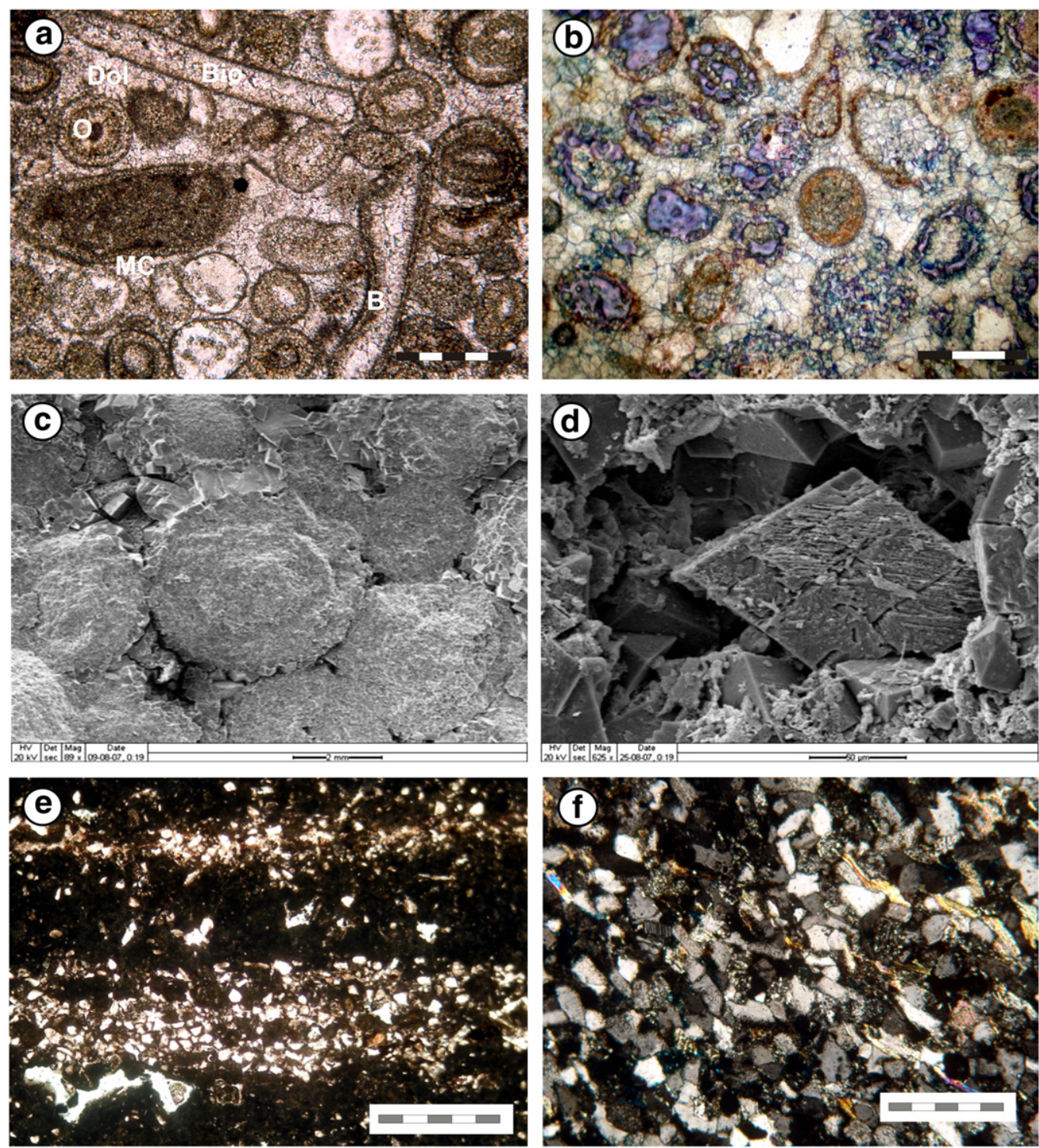

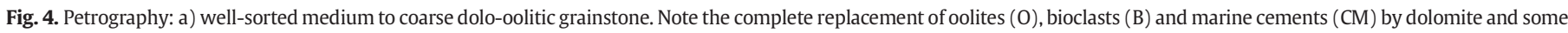

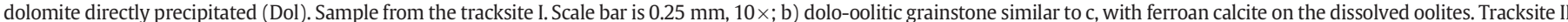

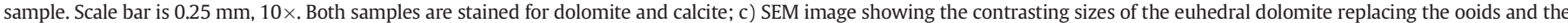

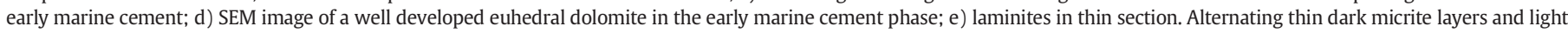

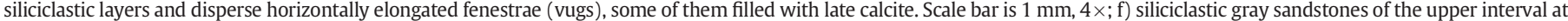
the tracksite I containing quartz, feldspars and scarce volcanic lithics. Scale bar is $0.5 \mathrm{~mm}, 4 \times$.

irregular mud cracking is probably due to desiccation and exposure of thin microbial mats. The record of Steinmanella is consistent with a suitable substratum for the bivalve that had shallow infaunal habits and is traditionally considered stenohaline (see Lazo, 2003).

Accordingly, these deposits record a different depositional setting dominated by settling from suspension, with different grades of oxygenation and water level fluctuations, from permanent subaqueous conditions up to exposure with incipient cracking.

\section{Theropod tracksites}

All footprints and trackways recorded in the tracksites I and II (Figs. 2b, 3c, 5a, c, d) correspond to obligated bipedal animals with functionally tridactyl digitigrade pes with no record of digits I and $V$ or metatarsus impressions, and bearing pointed claws marks. On both analyzed localities, the recorded footprints are arranged in several trackways and are preserved as natural moulds. Sedimentological analysis of the trackbearing beds strongly suggests that these surfaces correspond to the original printed surfaces.

\subsection{Tracksite I: Mina La Continental (Fig. 5a-c)}

\subsubsection{Description}

Most of the tracks are poorly preserved and only the general contour is evident, moreover some of them are just faint elongated depressions. The footprints are arranged in four parallel trackways orientated mainly north-south, and all show the same direction of movement of the trackmakers (Fig. 5a). These represent relatively large animals with obligated bipedal progression. The best preserved prints are clearly tridactyl and the pads of the digits are not discernible (Fig. 5c). Digit III is projected farther anteriorly than digits II and IV, which are, in contrast, of similar size; the divarication angle between digit III-II and III-IV is, 

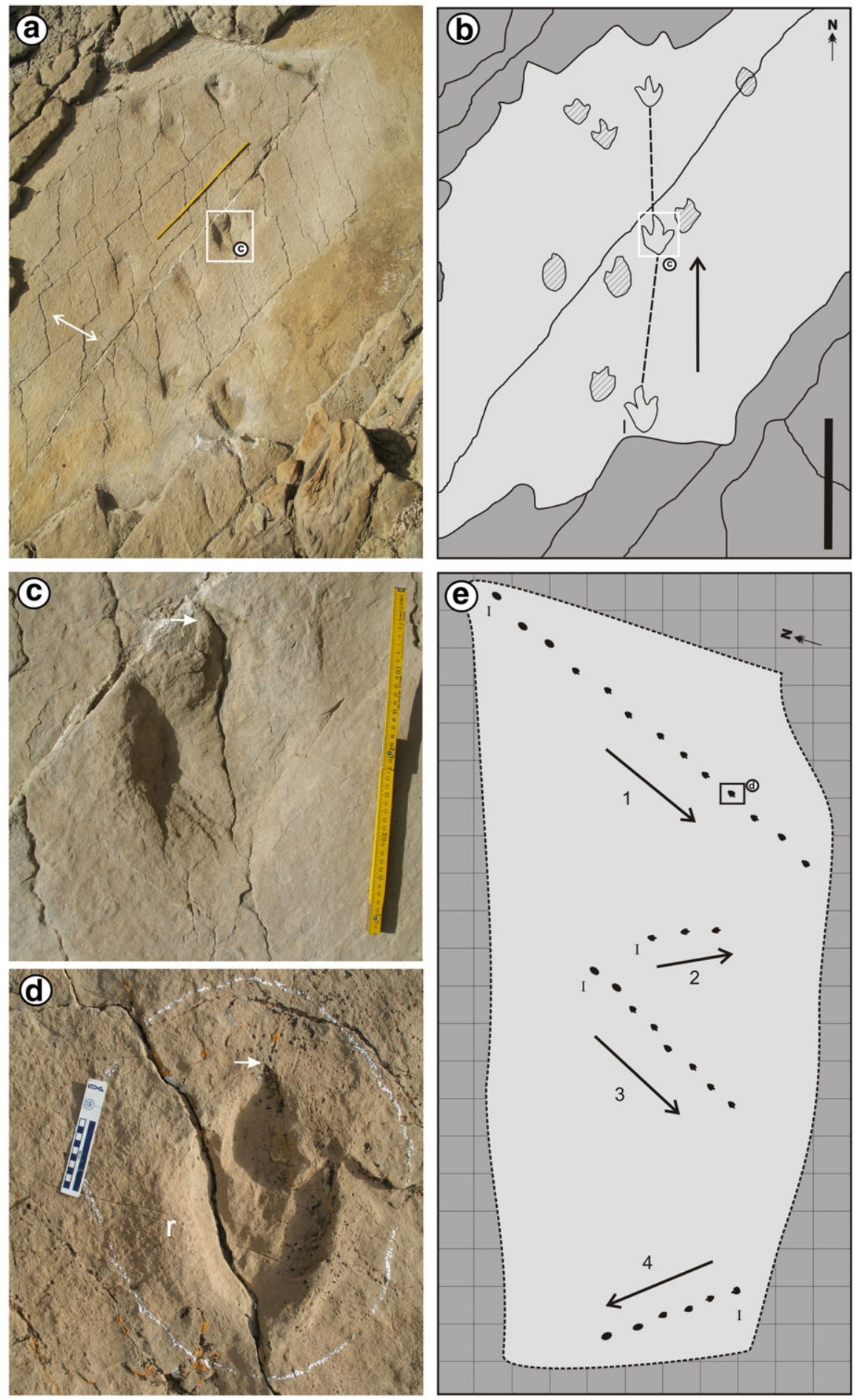

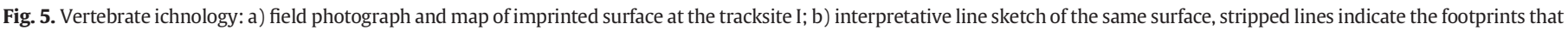

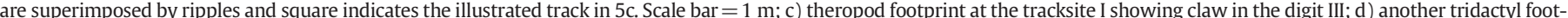

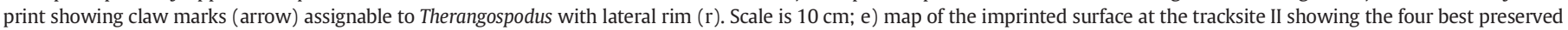
trackways and the location of the track illustrated in panel $\mathrm{d}$. The arrows indicate the direction of movement of the trackmakers. Grid pattern forms $1.5 \mathrm{~m}^{2}$.

approximately, $45^{\circ}$. Digit impressions bear narrow and pointed claws marks (Fig. 5c); digit III claw projects inwards. In general, all the prints are of equal size (Table 2) and the pace length in all measured trackways is, approximately, of $130 \mathrm{~cm}$. The high pace angulation (nearly $180^{\circ}$ ) in the trackways indicates that they correspond to bipeds with fully adducted hindlimbs. According to the trackway pattern in tracksite I and calculated measurements on the best preserved trackway, summarized in Table 2, suggest medium-size animals, of approximately $170 \mathrm{~cm}$ hip height (Thulborn, 1989, 1990; Henderson, 2003). Some of these tracks appear superimposed by small parallel ripple marks thus indicating that they were covered by water after their emplacement which affected their preservation. Nevertheless, one of the trackways shows the prints deeply impressed in the sediment and disturbing the ripples. This trackway was imprinted after withdrawal of the water, 
when the surface was exposed again, thus showing the presence of more than one trampling episode on the same surface with recurring shoreline excursions.

\subsection{Tracksite II: Cerro Rayoso (Fig. 5d,e)}

\subsubsection{Description}

At this locality, the imprinted surface is much more extensively exposed than the one described above (approx. $50 \mathrm{~m}$ length and $20 \mathrm{~m}$ width), and preserves several trackways and isolated footprints. As occurs in the surface described above from tracksite I, the trackways indicate the presence of relatively large animals with full bipedal progression.

The isolated footprints appear both on the western and eastern borders of the surface and show a random distribution with no evidence of overprinting. Four trackways are quite clearly visible in the middle of the exposed surface and are widely separated from each other. One of the trackways includes only three rather poorly preserved prints whereas the remaining three are longer (between 6 to 16 successive steps) with the prints rather deeply imprinted with a rim of displaced sediment around them. In general, each trackway includes the best preserved prints away from the northern border of the surface, which appears to be more affected by recent weathering. The tracks closer to this border are eroded and only preserved as rounded low depressions. In some cases, tracks apparently more protected by the presence of loose blocks on the surface even preserve their original sediment infilling. Nevertheless, among the different trackways the prints exhibit a slightly different degree of preservation apparently not due to recent weathering. Therefore, the observed differences in preservation indicate that the trackways were implanted at different times, may be days or weeks.

From west to east, the first well preserved trackway on the exposed surface consists of six consecutive tridactyl footprints. The first track of the series corresponds to a right pes and the direction of movement is, approximately, to the NNW. The digits are anteriorly directed with pads rather distinct. Digits II and IV are of nearly equal size, with digit III slightly longer and pads are not clear. The divarication angle between digit III-II and III-IV is $25-30^{\circ}$. Digit impressions have claws marks,
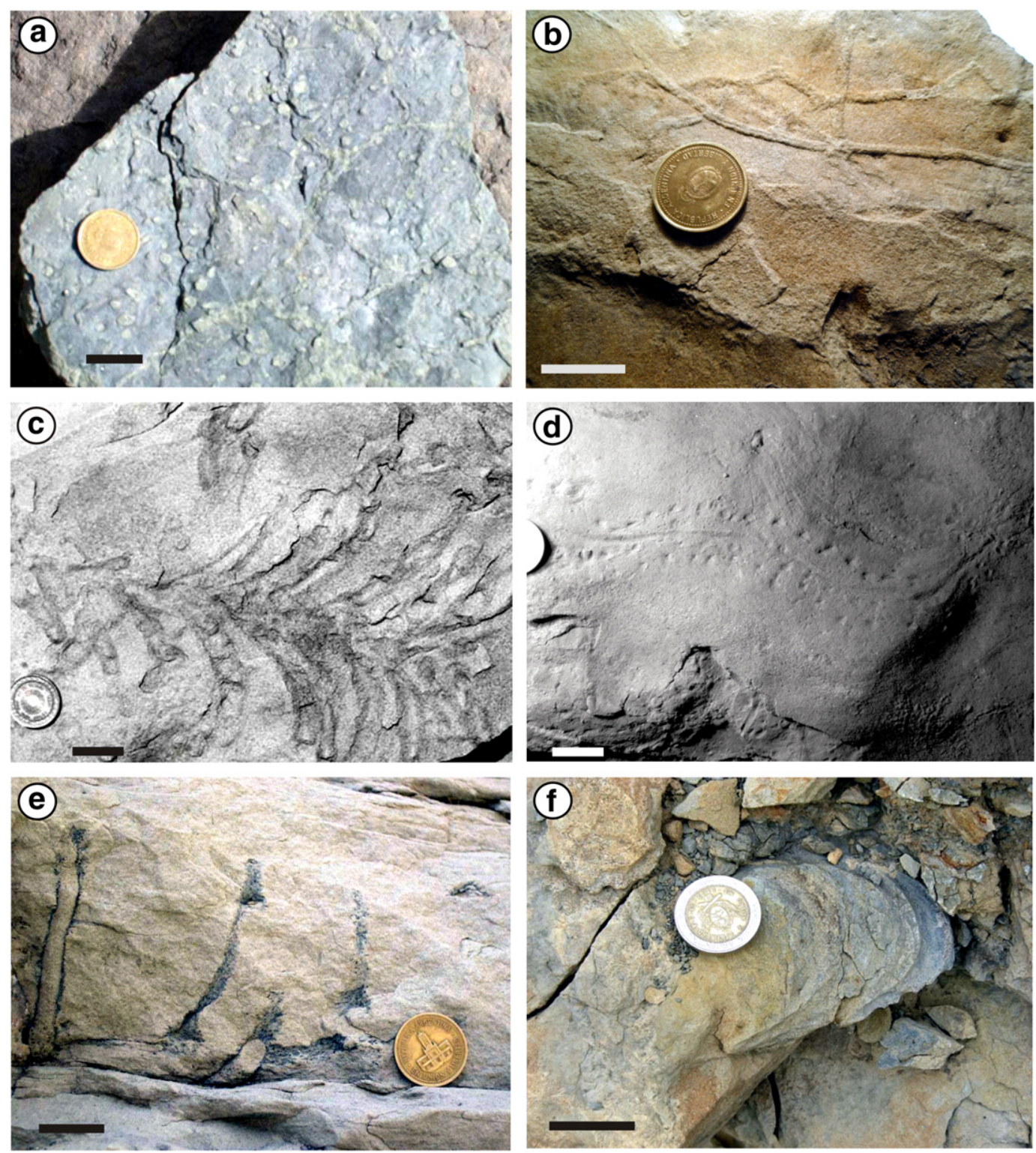

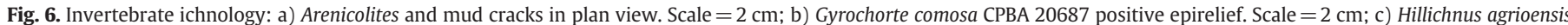

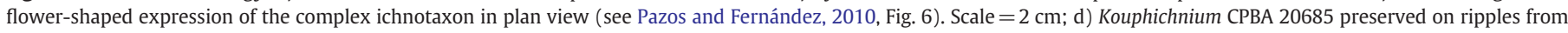

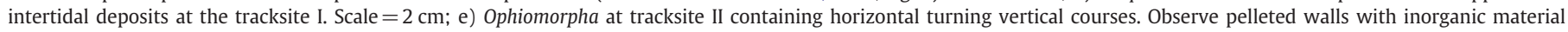
(micas). Scale $=2 \mathrm{~cm} ; \mathrm{f}$ ) Rhizocorallium in intertidal deposits at the tracksite I. Scale $=2 \mathrm{~cm}$. 
which are narrow-based and pointed and digit III claw is directed inwards. The average pace length is $1 \mathrm{~m}$ and the pace angulation is rather high $\left(160^{\circ}\right)$, thus suggesting a narrow upright stance for its maker. Trackway pattern and the presence of pointed claw marks (Fig. 5d) in the pes prints indicate that the trackmaker was a relatively mediumsized theropod dinosaur. According to Thulborn's ratios (Thulborn, 1989; Henderson, 2003) the calculated trackmaker's hip height is approximately $170 \mathrm{~cm}$.

The second trackway is about $10 \mathrm{~m}$ eastwards from the one described above. It includes 8 tracks of equivalent shape and size to those previously described. Moreover, the pace length and pace angulation are also very similar thus suggesting the same type of trackmaker. In contrast to the first trackway, this second one is orientated nearly north-south, and the prints indicated that the trackmaker was moving southward.

The third well preserved trackway on the surface is nearly 5 m eastwards from the second one and it comprises just three consecutive steps. As occurs with the previously described, it is orientated nearly north-south with the animal also moving southward, and the tracks are of equivalent shape and size to the ones previously described.

The longest fourth trackway recorded on the surface ( 14 footprints) is the closest to the eastern border of the exposed surface. In this case, the prints are also functionally tridactyl with pads not clear and the digits bear pointed claw marks. Nevertheless, the tracks are relatively smaller (Table 2) than the ones described in the other trackways. In this case, the prints are also more separated from each other (average pace length $120 \mathrm{~cm}$ ) thus suggesting the trackmaker was moving significantly faster than in the other trackways.

\subsection{Systematic Discussion}

The ichnological approach in the study of footprints has been based on the attempt of identification of the producer rather than merely the behaviour, taking into account that most records of vertebrate bioturbation, in particular dinosaurs, are locomotion, nesting or rarely swimming. Dealing ichnologically with footprints engulfed the differences with invertebrate ichnotaxonomy which is based on morphology and existence of behavioural convergence (homeomorphism) of tracemakers that some authors relate to osteology. Lucas (2007) pointed out that the shape of a footprint is determined not only by the structure of the foot (including skeleton and soft tissue) of the tracemaker but also by the interaction of the foot with the substrate. The influence of the substrate is crucial in the resultant morphology of a track, and permits to cast doubts on ichnotaxonomy based on extramorphological variants or substrate, including its type, consistency, humidity, slope and others. Lucas (2007) questioned most footprint ichnospecies and concluded that much ichnotaxonomic revision is needed before they can be used in biostratigraphy and biochronology. In the same way, Manning (2004) has shown that undertracks and substrate differences produce morphological variations, that may be an artifact if they are used in ichnotaxonomy introducing noise in ichnodiversity estimations. The scope of this paper is not a detailed ichnotaxonomy of the tracks but the occurrence of the tracks analyzed in a sedimentological context. However, several measurements on tracks at both tracksites (Table 2) permit to make a tentative systematic identification using simple parametres as size, pace angulation, morphology of digits, devarication angle between digits II-IV, existence of claws, pace length and devarication and length and wide ratio $(1 / \mathrm{w})$, but without forgetting that our material is compared in some cases with ichnogenera defined, unfortunately, without any reference to the type of substrate and its influence in the morphology of the footprints. We have a precise Early Cretaceous age which is a time particualry scarce in dinosaur's tracks.

Lockley $(1986,2009)$ 's analysis of morphological variations in tridactyl footprints is a starting point of the ichnotaxonomical discussion of our material. The prominent toe (digit III) is a feature shared by theropods, ornithopods and many terrestrial birds, with shorter digits II-IV and I (hallux), a condition referred to as mexasonic, being such digits more or less similar and subordinated in length (Lockley, 2009), a feature easily documented in our material, being the digit I absent. The presence of claw marks, long pace and almost $180^{\circ}$ in pace angulation permits to disregard ornithopods as producers and assign these tracks to theropods.

Lockley (2009) compared morphologically tridactyl, mesaxonic footprints of the type ichnospecies of Grallator, Anchisauripus and Eubrontes (GAE plexus) taking into account measurements such as overall size, length, width and mexasony showing a resultant typical "grallatorid pattern" that defines Grallator with a prominent digit III, and separates it from Anchisauripus and Eubrontes. The last two are characterised by a progressive shortening of the middle digit, without including claws. Eubrontes and Grallator are well known in the literature from classical literature about footprints. Olsen et al. (1998) noted that Eubrontes is usually bigger in size and shows less mesaxony than small Grallator footprints but dangerously lump all material into Grallator claiming that the type material of Eubrontes is lost, regardless than an iconotype may be valid in agreement with the ICZN. Lockley (2009) concluded that most of the tridactyl footprints documented in the Jurassic of China are indistinguishable from Eubrontes and Grallator using mexasony. Moreover, mesaxony of co-occurring tracks of Minisauripus and Eubrontes paradoxically exhibits no differences between these two ichnogenera using mexasony from the Cretaceous of China; this was explained as a heterochronic phenomenon indicating that the morphotype is independent of size in some cases (Lockley, 2009). Size is not a good ichnotaxobase in most of the cases, something well known in invertebrate ichnology (Bertling, 2007), but also mesaxony is not a determinant parameter, at least in some cases. With this premise, our material may be compared with other theropod footprints using morphometric values, such as overall size and $1 / \mathrm{w}$ ratios. The mean size (length) is $34.6(\mathrm{~N}=3)$ and $32.1(\mathrm{~N}=23)$ calculated for tracksites I and II, respectively (Table 2), and are similar to Eubrontes giganteous (Hitchcock), the type ichnospecies (see Lockley, 2009), but smaller than Megalosauripus, larger than Anchisauripus and much larger than typical grallatorid forms such as Grallator, Neograllator, Paragrallator, Carmelopodus, and Minisauripus.

Therangospodus, an ichnotaxon considered of medium size, was defined for footprints from Spain, USA and Turkmenistan by Lockley et al. (1998). The diagnosis of the ichnogenus included: size (which is here considered a questionable decision at ichnogeneric level) and the lack of defined phalangeal pads; these features are in general very similar to our material. We note that the measurements given in the ichnogenus description do not coincide much with the values calculated from the table 1 of Lockley et al. (1998). Probably due to this poor description, the ichnogenus has only been occasionally mentioned later in literature (e.g. Conti et al., 2005). However, it was later used as integrating the ichnofacies of Megalosauripus-Therangospodus for transgressive facies with tidal influence in the Jurassic of USA (Lockley et al., 2007). This ichnofacies is not recurrent in time and space (only known in the Jurassic of USA) and is more probably an ichnoassemblage rather than an ichnofacies. The presence of Therangospodus in deposits of dubious Late Jurassic-Early Cretaceous age from the Cameros Basin in Spain was used in favor of a Jurassic age for the unit (Lockley et al., 1998), which is also disputable.

Regardless that Eubrontes with a variety of sizes were found in the Late Triassic, which confirms that size is not a useful parameter at ichnogeneric level (as in invertebrates); we calculated morphometric measures of Therangospodus from data of the table 1 of Lockley et al. (1998) and used them to obtain the arithmetic mean of the length of their material and the $(1 / \mathrm{w})$ mean. The ratio $(1 / \mathrm{w})$ calculated by Lockley (2009, Fig. 2) for the type ichnospecies of Eubrontes is 1.7; it is 1.38 in Therangospodus and around 1.41 in our footprints, which makes our material more similar to Therangospodus than to Eubrontes. However, Olsen et al. (1998) emended the ichnogenus definition used by Lull (1953) and point out that the holotype is lost. Olsen et al. 
(1998, Fig. 4a) included in it all forms with length superior to $25 \mathrm{~cm}$. Therangospodus is an ichnogenus that presents a small devarication angle between digits, high pace angulation $\left(160^{\circ}-180^{\circ}\right)$, robust digits rather than slender, and a digit IV usually longer than digit II, not showing clear internal asymmetry of the digit III (Lockley et al., 1998) and weak mesaxony, all features similar to our described material which are not comparable with the holotype of Eubrontes redefined by Olsen et al. (1998). Therangospodus was mainly documented in the Jurassic of North America, Europe and Asia. This Asian record from Turkmenistan was documented in Oxfordian-Kimmeridgian carbonates (Lockley et al., 1998). The European reference by Conti et al. (2005) is from the Mediterranean Jurassic carbonates.

In the Jurassic-Cretaceous boundary in South America, Apesteguía and Gallina (2011) documented medium-size theropod tracks (with presence of claws), with petaloid digits that they compared to Limayichnus (Calvo, 1991) from Late Cretaceous continental deposits of the Neuquén Basin. However, Limayichnus lacks claw markings and was attributed to ornithopods by Calvo (1991). They also described a second morphotype (named E) that interpreted as a medium-sized theropod, without giving a name. Calvo (1991) erected several ichnogenera ("genera" in his work) from material documented in the Late Cretaceous Rio Limay Formation, Neuquén Basin. In some cases, the diagnosis is based on scarce material or lacks detailed morphometric parameters for comparison and a full revision is necessary to test the validity of the new ichnotaxa attributed to theropods as Abelichnus, Bressanichnus, Deferrarichnus and Picunichnus. Abelichnus was not compared with big-sized Eubrontes and Megalosauripus, and is probably a nomen nudum; mesaxony is weak and presents pads which are not comparable with our footprints. Bresanichnus and Deferrarichnus are small in size, present strong mexasony and a digit III large, with a clear grallatorid pattern. Picunichnus was defined just with one isolated footprint and presents a small hallux, laterally oriented pace, while pes angulation and stride are unknown.

Recently, Matsukuwa et al. (2006) and Li et al. (2011) studied an Early Cretaceous ichnofauna with theropod tracks from China and cast doubts about several ichnogenera previously described from that country. They also defined Corpulentapus, an ichnogenus with a $\mathrm{I} / \mathrm{w}$ ratio $=$ 1.09 , considerably inferior to our material. Interestingly, they include in their Table 2 a "big theropod" track that exhibits morphometric parameters similar to the specimens presented herein, such as size, $\mathrm{I} / \mathrm{w}$ ratio, and step but they do not add information about digits pace angulation.

The assemblage Megalosauripus-Therangospodus considered as indicative of the Late Jurassic by Lockley et al. (1998) does not include the material from Spain (Lucas, 2007, p. 21) because according to this author the material described by Lockley et al. (1998) awaits a revision. At this point we would have the option to "lump" our material into Eubrontes (sensu Olsen et al., 1998) and the possibility that these tracks are actually assignable to Eubrontes should not be completely disregarded. However, considering that size is not a good ichnotaxobase and that phalangeal pads are completely absent, we tentatively assign our material to cf.Therangospodus pandemicus (Lockley et al., 1998). In the case that Therangospodus resulted an invalid ichnogenus after revision, our material would still concur with the Eubrontidae pattern, and could therefore be included under E. pandemicus or under a new ichnogenus more widespread in the Cretaceous.

\section{Facies arrangement}

The logged section in tracksite I allowed an analysis of the internal vertical arrangement of the deposits. It is composed of two distinguishable intervals, a lower one dominated by cycles with a fining upward arrangement and an upper one with a more complex pattern. Conversely, in tracksite II further field work is necessary prior to any stacking pattern analysis.

\subsection{Lower mixed carbonate-siliciclastic tidally dominated interval}

This interval comprises several fining upward cycles. Each cycle starts with transgressive deposits composed of carbonates recording subtidal conditions, continues with sandy limestones, and finally heterolithic deposits of lower to upper intertidal settings. This trend is a typical feature of tidal progradation. Carbonates recording shallow-marine agitated waters (ooids) but also containing theropod tracks document a high frequency of sea level fluctuations related to tidal cyclicity. However, it is clear that subtidal deposits are replaced by thicker intertidal deposits. Laminites are traditionally interpreted as supratidal deposits in carbonates realms. They are documented overlying dark shales and finegrained heterolithic deposits and record desiccation of permanent deficient oxygenated lagoons. They are covered by subtidal or lower intertidal carbonates or sandy limestones that mark the starting of a new cycle.

Deposition of oolithic packstones and grainstones indicates subtidal conditions, shallow agitated waters and restricted terrigenous input. Ooids show low level of deformation or fragmentation and were not moved by strong currents or reworked by storms. The area of deposition was under fully marine conditions as marine cement is present. Fluctuations in the water level, related to a progressive regression permitted an early dolomitization in the meteoric zone with generation of an alkaline media that inhibited infaunal colonization. The dolomitization modified the substrate consistency from a loose into a firm one. Iron stains with eroded ooids at the level of the dinosaur tracks in tracksite I indicate that such substrates were exposed and probably their firmness was enhanced by microbial induced stabilization. Small oscillatory ripples in the bedding plane indicate that water incursions may be also controlled by wind as suggested Kvale et al. (2001) in the shoreline. Ripples affecting differentially some trackways suggest at least two events of bioturbation.

Considering that subtidal deposits also contain evidence of exposure it is clear that the frequency of fluctuations in the sea level was high, in the light that the dinosaur tracks were documented in the basal beds of the lower interval. Subtidal exposed pairs record the base of some vertical stacked tidally dominated cycles, with a progressive dominance of intertidal deposits. Stratigraphically upward evidence of intertidal conditions and exposure are reinforced, as well as reduction in carbonates by increasing siliciclastic input. Sandy limestones containing gastropods encrusted by bryozoans document deposition in lower intertidal areas that pass upwards to sandstone-dominated heterolithic deposits containing ripples with opposite paleocurrent directions and mud drapes. Bioclastic deposits dominated by gastropods are the infill of small and shallow channels in the tidal flat. The observed fining upward trend and top-flat ripples or the incipient desiccation cracks documented at the end of some cycles mark the complete progradation of a tidal cycle. In some cases, shales record permanent body waters, probably marshes, or supratidal deposits prior to the final desiccation.

\subsection{Upper wave-influenced siliciclastic interval}

This interval starts with a flooding surface that records a transgressive event. This is followed by dark gray shales deposited in permanent subaqueous conditions with reduced oxygenation and high preservation of organic matter in a restricted body of water, probably lagoonal. Sharp-based gray sandstones with offshore prograding frontal structures and internal combined and wave ripples represent the infilling of such lagoons by coastal siliciclastic input. This happened under permanent subaqueous and normal marine salinities with records of Hillichnus and Ophiomorpha (Pazos and Fernández, 2010). The interval ends with green sandstones and shales deposited in extended sand to mixed flats with evidence of subaerial exposure, as shown by top-flat ripples. The regional extent of these deposits from localities distant up to $70 \mathrm{~km}$ and their regular thickness suggest that erosion of the overlying fluvial deposits (Huitrín Formation) was negligible. 


\section{Paleoenvironmental framework}

The distribution of trace fossils in the studied sections evidences that they are absent in subtidal deposits. Agitated, clear, shallow, and warm waters (ooids) seemed to favour colonization, but loose substrate or alkaline environment related to early dolomitization established an inhospitable setting for bioturbators. Notably, these deposits are completely devoid of trace fossils (Table 1) but rich in fragmented marine remains (bryozoans, echinoid spines, bivalves). Dolomitization is a process that generates an alkaline environment (Bontognali et al., 2010). Vadose dolomitization is explained by different mechanisms (see Touir et al., 2009). In the Agrio Formation, Tunik et al. (2009) concluded that dilution of marine waters took place during lowering of the sea level, permitting mixing of marine and meteoric waters as the main reasons of such dolomitization. This early diagenetic dolomitization, conversely, gave consistency to the carbonates prior to exposure related to wind action. The firmness of the surface may be also microbially induced but some features described by Kvale et al. (2001) are not recognised in this small outcrop. Tracks affected by wave ripples also evidence high frequency cyclicity in the apparently continuous subtidally dominated deposits and constitute an unequivocal evidence of subaerial exposure of carbonates. Karstification was not documented probably due to alternating short periods of exposure rather than prolonged ones. Progressive lowering of sea level documented by the progradational stacking pattern enhanced the development of the intertidal facies, and the reduction of subtidal deposits. Intertidal settings favour the preservation of trace fossils like Arenicolites (Fig. 6a), Kouphichnium (Fig. 6d) and Rhizocorallium (Fig. 6f) as usually microbial mats could be given adequate substrate consistency and tidal cyclicity favours the cover of mud veneers that preserve epichnial traces. Intertidal deposits contain the peculiar fauna of heavily encrusted gastropods and bivalves. Such fauna is important to understand the salinity fluctuations and is a reliable element to compare with modern analogues. The presence of multilamellar cheilostome masses along with serpulids is reminiscent of some present-day occurrences associated with strong variations in salinity. In the Coorong Lagoon of Australia, build-ups of a cheilostome species can be found intergrown with serpulids (Bone and Wass, 1990). A new population explosion in 1989 has been related to an increased freshwater run-off and lowering of the salinity in this lagoon where salinities normally reach up to $70 \mathrm{ppt}$ (Bone, 1991). So salinity increase during the Late Holocene was one of the contributory parameters leading to the decline of the bryozoan's build-ups. Nutrient availability, temperature and water depth may also have played a controlling role. The ecology of bryozoans and serpulids indicates that whereas most bryozoans require a subtidal environment to thrive, serpulids can thrive within the intertidal regime (Bone and Wass, 1990). Freitas et al. (1994) reported another unusual recent co-occurrence of cheilostomes and serpulids in the Albufeira Coastal Lagoon in Portugal. This happened after heavy winter rainfall reduced the salinity in the lagoon from normal marine to about 6.5-9 ppt. Bryozoans and serpulids covered almost completely pebbles and other available hard substrata confined to the upper 3-4 $\mathrm{m}$ of the water column in which temperature during the day ranged between $14^{\circ}-18^{\circ} \mathrm{C}$ and the $\mathrm{pH}$ fluctuated between 8.0-8.7. According to these examples together with paleoecological data of potamidids and trigoniids it seems that salinity fluctuations occurred in the uppermost levels of the Agua de la Mula Member and this induced bryozoan and serpulid aggregations on bivalve and gastropod shells.

Laminites are very frequent in intertidal to supratidal environments (Flügel, 2004) but may be frequent in subaqueous deposits in lagoons during low oxygen availability and subsequent sulfidization by bacteria. This is the case of a subtropical lagoon in Brazil studied by Vasconcelos et al. (2006). The occurrence of laminites at the top of some cycles or intercalated in intertidal deposits or covered by subtidal deposits at the top of cycles suggest changes from inter to supratidal conditions rather than oxygen depleted lagoons.

Interestingly, Kouphichnium testifies subaerial exposure in a tidal cycle and mud drapes preserved such structures from subsequent cycles. The ichnotaxon Rhizocorallium has been considered a marine trace fossil (Fürsich, 1974) but Baucon (2008) documented it in exposed tidal flats, and tidal point bars. For this reason, monoespecific levels of Rhizocorallium are considered an example of dewatering and/or an early compactation producing firmness in the substrate. Arenicolites showing a variable distance between tubes on the same bedding plane may indicate ontogenic variations in the population of Arenicola-type tracemakers or decortication. It may also indicate fluctuations in sedimentation and erosion evidencing a more complex history of sedimentary fluctuations. Interstratification with abundant muddy deposits do not favor the last interpretation by absence of recognizable erosive processes that are only documented as small tidal creeks.

The upper interval containing Gyrochorte (Fig. 6b), Hillichnus (Fig. 6c) and Ophiomorpha (Fig. 6e) constitutes an interesting record. Firstly, tellinoid producers of Hillichnus have been considered stenohaline and their traces point out to such conditions that reinforce a subaqueous and marine scenario for siliciclastic gray sandstones. It also confirms a new transgressive episode overlying the dominated intertidal deposits of the lower section. Tellinoid bivalves are characterised for a fragile shell that reduce the fossilization potencial. Interestingly, tellinoids are firstly recognised in the basin by their traces as it is the case for xiphosurans (Fernández and Pazos, 2010); the latter also suggest very suitable conditions probably related to matting in intertidal setting as occurs in modern tidally dominated coasts of middle latitudes in North America and India.

\section{Paleogeographical and paleobiological significance}

The study of the uppermost meters of the Agrio Formation permitted to identify the presence of relatively large theropod dinosaurs in the basin during the Late Hauterivian-Early Barremian. The relatively large theropod footprints described herein constitute the oldest record of dinosaur tracks in the Neuquén Basin and one of the best documented in marine related deposits in South America. Previously, dinosaur footprints associated with tidal flat deposits were only mentioned from the Late Jurassic of Chile (Moreno and Pino, 2002) and the Late Cretaceous of Antarctica (Olivero et al., 2007). Moreover, this new record suggests the presence of relatively large theropods in the basin already during the Early Cretaceous, thus pre-dating by several dozens of million years their body-fossil record in the region. Some invertebrate ichnogenera like Hillichnus, attributed to tellinoid bivalves, or Kouphichnium, xiphosuran trackways, also well precede the bodyfossil record of the producers in the Neuquén Basin.

Tracksite I is composed of two distinctive sections, a lower interval containing stacked cycles of prograding tidal flats that evidence an overall infilling and shallowing upward trend. Subtidal deposits disappear in the top cycles while intertidal up to supratidal deposits are more abundant. Carbonates, mainly sandy limestones, are restricted to the lower interval. Oolithic packstones and grainstones are characteristic of shallow-marine subtidal deposits. The upper interval is mainly siliciclastic and starts with transgressive lagoonal shales, followed by prograding sandstones capped by sand flats. This upper interval is conspicuous in the southern part of the basin evidencing a clear alocyclic control in the stacked deposits.

Ichnologically, the theropod tracks in tracksite I document shoreline fluctuations probably related to wind action as oscillatory ripples affect the tracks. Early dolomitization and possible microbial stabilization gave firmness to the substrate permitting the preservation of the dinosaur prints. Conversely, an alkaline environment generated during early dolomitization may explain the absence of invertebrate trace fossils in such inhospitable conditions. The interpretation of intertidal dominated deposits is reinforced by the presence of gastropods and bivalves encrusted with multilayered bryozoans. This depositonal setting, favored the trace fossil record (Arenicolites, Rhizocoralium) by successive veneers of mud in heterolithic deposits. The upper interval ichnofauna composed of Gyrochorte, Hillichnus and Ophiomorpha, documenting 
permanent submerged conditions related to a basinal widespread short-lived transgression.

This contribution demonstrates the complexity and high frequency of changes in the paleoenvironmental conditions of the uppermost part of the Agrio Formation. It emphasizes the role of tidal action rather than storms as traditionally accepted for this ramp and also demonstrate that siliciclastic deposits are the main constituent of the succession rather than a carbonate dominated depositional setting as suggested by Archuby and Fürsich (2010). It also explains the absence of ammonoids, nannoplankton and other stenohaline biotas by paleoenvironmental controls rather than by erosion during a sea level drop related to the deposition of the overlying Huitrín Formation.

The paleogeography of the Neuquén Basin during the deposition of the uppermost part of the Agua de la Mula Member of the Agrio Formation is, after our analysis, remarkably different from that previously considered. According to the more accepted paleogeographic schemes fully marine littoral conditions were interpreted for the studied area during Early Cretaceous times (Legarreta, 2002). After our analysis tidal activity and high frequency cyclicity are the most suitable mechanisms to explain the observed mixed siliciclastic-carbonate cycles.

\section{Conclusions}

For the first time, the presence of theropod dinosaurs is recorded in the Neuquén Basin during the Early Cretaceous thus preceding by dozens of million years the body-fossil record of non-avian dinosaurs in this part of Patagonia and for middle size carnivores. These tracks are assigned to cf. Therangospodus pandemicus (Lockley et al., 1998) and they constitute one of the scarce undisputable Early Cretaceous theropod tracks, particularly in Gondwanan carbonates and also in the world.

Tracks are documented in subtidal grainstones and packstones with notable early diagenetic dolomitization related to the vadose zone. The surface with the dinosaur tracks at tracksite I contains wave ripples that affected selectively some sets of tracks evidencing more than one stage of trampling and fluctuations in the coast line, probably related to wind action. Dinosaur tracks contrast with previous facies models that suggested a storm-dominated carbonate ramp.

Dolomitization and possible microbial stabilization of the substrate gave firmness to the trampling surface thus enhancing the preservation of the tracks. The studied tracks constitute an unequivocal evidence of subaerial exposure of the subtidal deposits, barren of trace fossils.

Heterolithic intertidal deposits contain a diverse ichnofauna composed of Arenicolites, Kouphichnium and Rhizocorallium. Kouphichnium is produced by xiphosurans and therefore this record constitutes the first illustrated evidence of these animals in Mesozoic rocks of South America.

Tidally-influenced deposits are stacked in fining upward metric cycles related to progradation. Laminites are records of upper intertidal to supratidal settings. Bioclastic deposits contain abundant potamidid gastropods highly encrusted by multilamellar bryozoans typical of intertidal areas and probably evidencing salinity fluctuations after comparison with modern counterparts.

The upper interval only documented at tracksite I is a transgressiveregressive cycle that marks the last depositional transgressive event in the Agrio Formation. It contains in a siliciclastic wave-influenced prograding wedge an ichnofauna composed of Gyrochorte, Hillichnus, and Ophiomorpha. Hillichnus documents the presence of tellinoid bivalves, which body fossils are at present unknown in the basin.

Tracksite II is a coarsening upward short interval that contains siliciclastic wave-influenced to tidal-influenced deposits with Ophiomorpha capped by subtidal carbonates with more than two dozens of dinosaur footprints preserved in a high tilted surface.

In both tracksites the absence of traditionally used biostratigraphic markers as ammonoids and nannoplankton is easily explained by paleoenvironmental control rather than erosion linked with the overlying sequence boundary related to the Huitrín Formation. Thus, our study challenges previous facies model belts that suggested permanent submerged littoral facies for this part of the basin during the Early Cretaceous and reinforce the control of tidal cycles in the facies architecture. This is the first time that integration of ichnological and sedimentological data is used to refine depositional schemes in one of the most important marine intervals of the Early Cretaceous in the Neuquén Basin, and in one of the more studied oil producer and reservoir units in Patagonia.

\section{Acknowledgements}

Marian Tanuz and Victor Ramos (Universidad de Buenos Aires) are thanked for their help during fieldwork. Miguel Griffin (Museo de La Plata) and Cecilia Cataldo (Universidad de Buenos Aires) are acknowledged for their help in the identification of fossil gastropods. Fernando Novas and Sebastián Apesteguía provided literature and Marco Avanzini helped with inaccessible literature from Europe. Peter Rawson (UK) was crucial to improve the English in an early version of the manuscript. This work was supported by grants ANPCYT PICT 0464/2010 and UBACyT x 001 to M.B. Aguirre-Urreta and UBACyT Ex 387 to P. J. Pazos. This is the contribution R-23 of the Instituto de Estudios Andinos "Don Pablo Groeber" (IDEAN). PJP dedicate this paper to the memory of NCP.

\section{References}

Aguirre-Urreta, M.B., Rawson, P.F., Concheyro, G.A., Bown, P.R., Ottone, E.G., 2005. Lower Cretaceous Biostratigraphy of the Neuquén Basin. In: Veiga, G.D., Spalletti, L.A., Howell, J.A., Schwarz, E. (Eds.), The Neuquén Basin: a case study in sequence stratigraphy and basin dynamics: The Geological Society, London, Special Publication, 252. pp. 57-81.

Aguirre-Urreta, M.B., Pazos, P.J., Lazo, D.G., Fanning, C.M., Litvak, V.D., 2008. First U-Pb shrimp age of the Hauterivian stage, Neuquén Basin, Argentina. Journal of South American Earth Sciences 26, 91-99.

Aguirre-Urreta, M.B., Tunik, M., Naipauer, P.J., Pazos, E., Ottone, M. Fanning, Ramos, V.A., 2011. Malargüe Group (Maastrichtian-Danian) deposits in the Neuquén Andes, Argentina: implications for the onset of the first Atlantic transgression related to Western Gondwana break-up. Gondwana Research 19, 482-494.

Apesteguía, S., 2007. The sauropod diversity of the La Amarga Formation (Barremian), Neuquén (Argentina). Gondwana Research 12, 533-546.

Apesteguía, S., Gallina, P., 2011. Tunasniyoj a dinosaur tracksite from the Jurassic-Cretaceous boundary of Bolivia. Anais da Academia Brasileira de Ciências 83, 267-277.

Archuby, F., Fürsich, F., 2010. Facies analysis of a highly cyclic sedimementary unit: the Late Hauterivian to Early Barremian Agua de la Mula member of the Agrio Formation, Neuquén basin, Argentina. Beringeria 4, 1-54.

Bandel, K., Kowalke, T., 1999. Gastropod fauna of the Cameroonian coasts. Helgoland Marine Research 53, 129-140.

Barnes, R.S.K., 2003. Interactions between benthic mollusks in a Sulawesi mangal, Indonesia: the cerithiid mud-creeper Cerithium coralium and potamidid mud-whelks, Terebralia spp. Journal of the Marine Biological Association of the UK 83, 483-487.

Baucon, A., 2008. Neoichnology of microbial mat in a temperate, siliciclastic environment: Spiaggia al Bosco (Grado, Northern Adriatic, Italy). Studi Trentini di Scienze Naturali, Acta Geologica 83, 183-203.

Belvedere, M., Dyke, G., Hadri, M., Ishigaki, S., 2011. The oldest evidence for birds in Northern Gondwana? Small tridactyl footprints from the Middle Jurassic of Msemrir (Morocco). Gondwan Research 19, 542-549.

Bertling, M., 2007. In: Miller III, W. (Ed.), Trace fossil concepts, problems, prospects. What's in a name? : Nomenclature, Systematics, Ichnotaxonomy, Chapter II (5), pp. 81-91.

Bonaparte, J.E., 1996. Cretaceous tetrapods of Argentina. Münchner Geowissenschftliche Abhandlungen, A 30, 73-130.

Bone, Y., 1991. Population explosion of the bryozoan Membranipora aciculata in the Coorong Lagoon in late 1989. Australian Journal of Earth Sciences 38, 121-123.

Bone, Y., Wass, R.E., 1990. Sub-recent bryozoan-serpulid build-ups in the Coorong Lagoon, South Australia. Australian Journal of Earth Sciences 37, 207-214.

Bontognali, T.R.R., Vasconcelos, C., Warthmann, R.J., Bernasconi, S.M., Dupraz, C. Strohmenger, C.J., Mckenzie, J.A., 2010. Dolomite formation within microbial mats in the coastal sabkha of Abu Dhabi (United Arab Emirates). Sedimentology 57, $824-844$.

Calvo, J.O., 1991. Huellas fósiles de dinosaurios en la Formación Río Limay (Albiano-Cenomaniano), Picún Leufú, Provincia del Neuquén, Argentina. (Ornithischia-Saurischia: Saurópoda-Terópoda). Ameghiniana 28, 241-258.

Calvo, J.O., 2007. Ichnology. In: Gasparini, Z., Coria, R.A., Salgado, L. (Eds.), Patagonian Mesozoic Reptiles. Indiana University Press, Bloomington, pp. 314-334.

Calvo, J.O., Mazzetta, G.V., 2004. Nuevos hallazgos de huellas de Dinosaurios en la Formación Río Limay (Albiano-Cenomaniano), Picún Leufú, Neuquén, Argentina. Ameghiniana 41, 545-554. 
Casamiquela, R.M., 1964. Estudios icnológicos. Problemas y métodos de la icnología con aplicación al estudio de pisadas mesozoicas (Reptilia, Mammalia) de la Patagonia. Colegio Industrial Pio IX, Buenos Aires. (229 pp.)

Cichowolski, M., Pazos, P.J., Tunik, M.A., Aguirre-Urreta, M.B., 2012. An exceptional storm accumulation of nautilids, Lower Cretaceous, Neuquén Basin, Argentina. Lethaia 45, 121-138.

Conti, M.A., Morsilli, M., Nicosia, U. Sacchi, Savino, V., Wagensommer, A. Di, Maggio, L., Gianolla, P., 2005. Jurassic dinosaur footprints from Southern Italy: footprints as indicator of constraints in paleogeographic interpretation. Palaios 20, 534-550.

Coria, R.A., 2007. Non-avian theropods. In: Gasparini, Z., Coria, R.A., Salgado, L. (Eds.) Patagonian Mesozoic Reptiles. Indiana University Press, Bloomington, pp. 229-256.

Dawans, J.M., Swart, P.K., 1988. Textural and geochemical alternations in Late Cenozoic Bahamian dolomites. Sedimentology 35, 385-403.

Dietrich, C., 2002. Vertebrate track bed stratigraphy at new mega track sites in the Upper Wellenkalk Member and orbicularis Member (Muschelkalk, Middle Triassic) in carbonate tidal flat environments of the Western Germanic Basin. Palaeogeography, Palaeoclimatology, Palaeoecology 183, 185-208

Dietrich, C., 2008. Millions of reptile tracks-Early to Middle Triassic carbonate tidal flat migration bridges of central Europe-reptile immigration into the Germanic Basin. Palaeogeography, Palaeoclimatology, Palaeoecology 299, 410-423.

Dunham, R.J., 1962. Classification of carbonate rocks according to depositional texture. American Association of Petroleum Geologists Memoir 1, 108-121 (AAPG, Tulsa).

Fernández, D.E., Pazos, P.J., 2010. Xiphosurid trackways in a marginal marine setting from the Lower Cretaceous (Agrio Formation) of the Neuquén Basin, Argentina. $I^{\circ}$ Latin-American Symposium on Ichnology. Abstracts, p. 37 (UNISINOS, São Leopoldo, Brazil).

Fernández, D.E., Pazos, P.J., Aguirre Urreta, M.B., 2010. Protovirgularia dichotoma-Protovirgularia rugosa: an example of a compound trace fossil from the Lower Cretaceous (Agrio Formation) of the Neuquén basin, Argentina. Ichnos 17(1), 40-47.

Flügel, E., 2004. Microfacies of Carbonate Rocks. Analisis, Interpretation and Application. Springer-Verlag, Berlin-Heidelberg. (976 pp.).

Folk, R., Andrews, P., Lewis, D., 1970. Detrital sedimentary rock classification and nomenclature for use in New Zeland. New Zeland Journal of Geology and Geophysics 13, 937-968.

Freitas, M.C., Cachao, M., Cancela da Fonseca, L., Caroça, C., Galopim de Carvalho, A.M., 1994 Unusual co-occurrence of serpulids and Bryozoa in a lagoonal system (Albufeira Coastal Lagoon-Portugal). Gaia 8, 39-46.

Fürsich, F.T., 1974. Ichnogenus Rhizocorallium. Paläontologische Zeitschrift 48, 16-28.

Gregg, J.M., Sibley, D.F., 1984. Epigenetic dolomitization and the origin of xenotopic dolomite texture. Journal of Sedimentary Petrology 54, 908-931.

Henderson, D.M., 2003. Footprints, trackways, and hip heights of bipedal dinosaurs-testing hip height predictions with computer models. Ichnos 10, 99-114.

Houbrick, R.S., 1984. Revision of higher taxa in genus Cerithidea (Mesogastrooda: Potamididae) based on comparative morphology and biological data. American Malacological Bulletin 2, 1-20.

Houbrick, R.S., 1986. Cerithioidean phylogeny. In: Ponder, W.F. (Ed.), Prosobranch Phylogeny: Malacological Review Supplement, 4, pp. 88-128.

Keen, M., 1958. Sea shells of tropical west America. Marine mollusks from Lower California to Colombia. Stanford University Press, California, USA. (626 pp.).

Kidwell, S.M., Bosence, D.W.J., 1991. Taphonomy and Time-Averaging of marine shelly faunas. In: Allison, P.A., Briggs, D.E.G. (Eds.), Taphonomy: releasing the data locked in the fossil record. : Topics in Geobiology, 9. Plenum Press, New York, pp. 115-209.

Kowalke, T., 2002. Systematic revision of Palaeocene brackish water Gastropoda from Mons, Belgium, based on their early ontogenetic shells. Bulletin de l'Institut Royal des Sciences Naturelles de Belgique, Sciences de la terre 72, 111-134.

Kvale, E.P., Johnson, G.D., Michelson, D.L., Keller, K., Furer, L.C., Archer, A.W., 2001. Middle Jurassic (Bajocian and Bathonian) dinosaur megatracksites, Bighorn Basin, Wyoming U.S.A. Palaios 16, 233-254

Lazo, D.G., 2003. The genus Steinmanella (Bivalvia, Trigonioida) in the Agrio Formation (Lower Cretaceous), Neuquén Basin, Argentina. Journal of Paleontology 77, 1069-1085.

Lazo, D.G., Cichowolski, M., Rodríguez, D.L., Aguirre-Urreta, M.B., 2005. Lithofacies, palaeoecology and palaeoenvironments of the Agrio Formation, Lower Cretaceous of the Neuquén Basin, Argentina. In: Veiga, G.D., Spalletti, L.A., Howell, J.A., Schwarz, E. (Eds.), The Neuquén Basin, Argentina: a case study in sequence stratigraphy and basin dynamics. : Geological Society of London, Special Publications, 252. The Geological Society, pp. 295-315

Lazo, D.G., Aguirre-Urreta, M.B., Price, G.D., Rawson, P.F., Ruffell, A.H., Ogle, N., 2008 Palaeosalinity variations in the Early Cretaceous of the Neuquén Basin, Argentina: evidence from oxygen isotopes and palaeoecological analysis. Palaeogeography, Palaeoecology, Palaeoclimatology 260, 477-493.

Leanza, H.A., Hugo, C.A., Repol, D., 2001. Hoja Geológica 3969-I, Zapala, provincia del Neuquén. Instituto de Geología y Recursos Minerales. : Servicio Geológico Minero Argentino, Boletín, 275, SEGEMAR, Buenos Aires, p. 128

Leanza, H.A., Apesteguía, S., Novas, F.E., De la Fuente, M.S., 2004. Cretaceous terrestrial beds from the Neuquén Basin (Argentina) and their tetrapod assemblages. Cretaceous Research 25, 61-87.

Legarreta, L., 2002. Eventos de desecación en la Cuenca Neuquina: Depósitos continentales y distribución de hidrocarburos. V Congreso de Exploración de Hidrocarburos. Actas, CD-ROM.

Legarreta, L., Uliana, M.A., 1999. El Jurásico y Cretácico de la Cordillera Principal y la Cuenca Neuquina. I, Facies sedimentarias. In: Caminos, R. (Ed.), Geología Argentina. SEGEMAR, Buenos Aires, pp. 399-416.

Li, R., Lockley, M.G., Matsukawa, M., Wang, K., Liu, M., 2011. An unusual theropod track assemblage from the Cretaceous of Zhuccheng area, Shandong Province, China. Cretaceous Research 32, 422-432.

Lockley, M.G., 1986. The paleobiological and paleoenvironmental importance of dinosaur footprints. Palaios 1, 37-47.
Lockley, M.G., 2009. New perspective on morphological variation in tridactilar footprints: clues to widespread convergence in developmental dynamics. Geological Quarterly 53, 415-432.

Lockley, M.G., Mayer, Ch.A., Moratalla, J.J., 1998. Therangospodus: trackway evidence for the widespread distribution of a Late Jurassic theropod with well-padded feet. Gaia $15,339-353$.

Lockley, M.G., Mitchell, L., Odier, G.P., 2007. Small theropod track assemblages from Middle Jurassic eolianites of Eastern Utath: paleoecological insights from dune ichnofacies in a transgresive sequence. Ichnos 14, 131-142.

Lucas, S.G., 2007. Tetrapod footprint biostratigraphy and biochronology. Ichnos 14, $5-38$.

Lull, R.S., 1953. Triassic life of the Connecticut Valley. Connecticut State Geological Natural History Survey Bulletin, 24 (35 pp.).

Manceñido, M.O., Damborenea, S.E., 1984. Megafauna de invertebrados paleozoicos y mesozoicos. In: Ramos, V.A. (Ed.), Geología y recursos naturales de la Provincia de Río Negro. $9^{\circ}$ Congres-o Geol-ógico Arg-entino, Buenos Aires, pp. 413-465.

Manning, P.L.A., 2004. A new approach to the analysis and interpretation of tracks: examples from Dinosauria. In: Mcllory, D. (Ed.), The application of Ichnology to palaeoenvironmental and tratigraphic analysis: Geological Society of London, Special Publications, 228, pp. 157-178

Matsukuwa, M., Lockley, M.G., Li, J., 2006. Cretaceous terrestrial biotas of East Asia, with special reference to dinosaur-dominated ichnofaunas: toward a synthesis. Cretaceous Research 27, 3-21.

Moreno, K., Pino, M., 2002. Huellas de dinosaurios en la Formación Baños del Flaco (Tithoniano-Jurásico Superior), VI Región, Chile: paleoetología y paleoambiente. Revista Geológica de Chile 29, 191-206.

Mount, J., 1984. Mixed siliciclastic and carbonate sediments: a proposed first-order textural and compositional classification. Sedimentology 32, 435-442.

Nicosia, U., Petti, F.M., Perugini, G., Dorazi Porchetti, S., Sacchi, E., Conti, M.A., Mariotti, N., 2007. Dinosaur tracks as paleogeographic constraints: new scenarios for the Cretaceous geography of the Periadriatic Region. Ichnos 14, 69-90.

Olivero, E., Ponce, J.J., Marsicano, C.A., Martinioni, D.R., 2007. Depositional setting of the basal López de Bertodano Formation, Maastrichtian, Antarctica. Revista Asociación Geológica Argentina 62, 521-529.

Olsen, P., Smith, J.B., McDonald, N.G., 1998. Type material of the type species of the classic theropod footprint genera Eubrontes, Anchisauripus, and Grallator (Early Jurassic, Hartford and Deerfield Basins, Connecticut and Massachusetts, USA). Journal of Vertebrate Paleontology 18, 586-601.

Pazos, P.J., 2009. Síntesis icnológica de las unidades marinas de la cuenca Neuquina, nuevos datos y perspectivas. Revista Asociación Geológica Argentina 65, 362-372.

Pazos, P.J., Fernández, D.E., 2010. Tridimentionally integrated trace-fossils from shallow marine deposits in the Lower Cretaceous of the Neuquén Basin: Hillichnus agrioensis isp. nov. Acta Geologica Polonica 60, 105-118.

Pazos, P.J., Fernández, D.E., Lazo, D.G., Tunik, M., Marsicano, C., Aguirre-Urreta, M.B., 2008. Ichnology of mixed carbonate-siliciclastic tidal flats, Lower Cretaceous, Neuquén basin, Argentina. 2nd. International Congress on Ichnology (Kracov), Abstracts, 99

Petti, F.M., D'Orazi Porchetti, S., Sacchi, E., Nicosia, U., 2010. A new purported ankylosaur trackway in the Lower Cretaceous (lower Aptian) shallow-marine carbonate deposits of Puglia, southern Italy. Cretaceous Research 31, 546-552.

Ramos, V.A., 1978. Estructura. In: Ramos, V.A. (Ed.), Geología y recursos naturales de la Provincia de Río Negro. $9^{\circ}$ Congres Geológico Argentino, Buenos Aires, pp. 413-465.

Sacchi, E., Conti, M.A. D'Orazi Porchetti, S. Logoluso, A Nicosia, U., Perugini, G, Petti, F.M. 2009. Aptian dinosaur footprints from the Apulian platform (Bisceglie, Southern Italy) in the framework of periadriatic ichnosites. Palaeogeography, Palaeoclimatology, Palaeoecology 271, 104-116.

Salgado, L., Bonaparte, J.F., 1991. Un nuevo saurópodo Dicraeosauridae Amargasaurus cazaui gen. et sp. nov. de la Formación La Amarga. Neocomiano de la provincia del Neuquén. Ameghiniana 28, 333-346.

Sibley, D., Gregg, J., 1987. Classification of dolomite rock textures. Journal of Sedimentary Petrology 57, 967-975.

Spalletti, L.A., Poiré, D., Pirrie, D., Matheos, S., Doyle, P., 2001. Respuesta sedimentológica a cambios en el nivel de base en una secuencia mixta clástica-carbonática del Cretácico de la cuenca Neuquina, Argentina. Revista de la Sociedad Geológica de España 14, 57-74.

Strasser, A., 1986. Ooids in Purbeck limestones (lowermost Cretaceous) of Swiss and French Jura. Sedimentology 33, 711-727.

Strömback, A., Howell, J.A., Veiga, G.D., 2005. The transgression of an erg-sedimentation and reworking/soft sediment deformation of Aeolian facies: the Cretaceous Troncoso Member, Neuquén basin, Argentina. In: Veiga, G.D., Spalletti, L.A., Howell, J.A., Schwarz, E. (Eds.), The Neuquén Basin, Argentina: a case study in sequence stratigraphy and basin dynamics. : Geological Society Special Publication, 252, The Geological Society, London, pp. 163-184.

Taylor, P.D., Lazo, D.G., Aguirre-Urreta, M.B., 2009. Early Cretaceous bryozoans from Argentina: a 'by-catch' fauna from the Agrio Formation (Neuquén Basin). Cretaceous Research 30, 193-203.

Thulborn, R.A., 1989. The gaits of dinosaurs. In: Gillette, D.D., Lockley, M.G. (Eds.), Dinosaur tracks and traces. Cambridge University Press, Cambridge, pp. 39-50.

Thulborn, T., 1990. Dinosaur tracks. Chapman \& Hall, London. (410 pp.).

Touir, J., Soussi, M., Troudi, J., 2009. Polyphased dolomitization of a shoal-rimmed carbonate platform: example from the middle Turonian Bireno dolomites of central Tunisia. Cretaceous Research 30, 785-804.

Tunik, M.A., Pazos, P.J., Impiccini, A., Lazo, D., Aguirre-Urreta, M.B., 2009. Dolomitized tidal cycles in the Agua de la Mula Member of the Agrio Formation (Early Cretaceous), Neuquén Basin, Argentina. Latin American Journal of Basin Analysis $16,29-43$ 
Vahrenkamp, V., Swart, P., 1994. Late Cenozoic dolomites of the Bahamas: metastable analogues for the genesis of ancient platform dolomites. In: Purser, B., Tucker, M., Zenger, D. (Eds.), Dolomites. A Volume in Honour of Dolomieu: International Association of Sedimentologist. Special Publication, 21, pp. 133-153.

Vasconcelos, C., Warthmann, R., McKenzie, J.A., Visscher, P.T., Bittermann, A.G., van Lith, I., 2006. Lithifying microbial mats in Lagoa Vermelha, Brazil: modern Precambrian relics? Sedimentary Geology 185, 175-183.

Veiga, G.D., Spalletti, L.A., 2007. The Upper Jurassic (Kimmeridgian) fluvial/aeolian systems of southern Neuquén Basin, Argentina. Gondwana Research 11, 286-302.

Veiga, G.D., Spalletti, L.A., Flint, S., 2002. Aeolian/fluvial interactions and high resolution sequence stratigraphy of a non-marine lowstand wedge: the Avilé Member of the Agrio Formation (Lower Cretaceous), central Neuquén Basin, Argentina. Sedimentology 49, 1001-1019.

Veiga, G.D., Howell, J.A., Strömbäck, A., 2005. Anatomy of a mixed marine-nonmarine lowstand wedge in a ramp setting. The record of the Barremian-Aptian complex rel- ative sea-level fall in the central Neuquén basin, Argentina. In: Veiga, G.D., Spalletti, L.A., Howell, J.A., Schwarz, E. (Eds.), The Neuquén Basin, Argentina: a case study in sequence stratigraphy and basin dynamics. : Geological Society Special Publication, 252, The Geological Society, London, pp. 163-184.

Warren, J., 2000. Dolomite: occurrence, evolution and economically important associations. Earth-Science Reviews 52, 1-81.

Weaver, C.E., 1931. Paleontology of the Jurassic and Cretaceous of West Central Argentina. Memoirs of the University of Washington 1, 1-595.

Zarcone, G., Petti, F.M., Cillari, A., Di Stefano, P., Guzzetta, D., Nicosia, U., 2010. A possible bridge between Adria and Africa: new palaeobiogeographic and stratigraphic constraints on the Mesozoic palaeogeography of the Central Mediterranean area. Earth-Science Reviews 103, 154-162.

Zonneveld, J.P., Gingras, M.K., Pemberton, S.G., 2001. Trace fossil assemblages in a Middle Triassic mixed siliciclastic-carbonate marginal marine depositional system, British Columbia. Palaeogeography, Palaeoclimatology, Palaeoecology $166,249-276$. 